\section{PAISAJE SONORO Y TERRITORIO. EL CASO DEL BARRIO SAN NICOLÁS EN CALI, COLOMBIA*}

Joaquín Llorca**

\section{Resumen:}

Además de la arquitectura y el espacio urbano, el ambiente contribuye, por encima de cualquier delimitación administrativa, a conformar territorios cargados de sentido para los sujetos. El presente artículo aborda la relación entre espacio y sonido, entendida como paisaje sonoro, en el barrio San Nicolás de Cali, un lugar con gran tradición que está próximo a sufrir cambios debido a políticas de renovación urbana y a las dinámicas de modernización en la industria gráfica, actividad que predomina e identifica el sector. Además de viviendas, el barrio aloja desde 1894 una gran cantidad de pequeños locales dedicados a la imprenta que

\section{SOUNDSCAPE AND TERRITORY. THE CASE OF SAN NICOLÁS, CALI, COLOMBIA*}

Joaquín Llorca**

\section{Abstract}

Apart from architecture and the urban space, the environment also contributes -beyond any administrative delimitation - to the generation of meaningful territories. This paper addresses the relationship that exists between space and sound -understood as soundscape - in San Nicolás de Cali, a traditional place that is about to experience some changes as the result of the implementation of urban renewal policies and the modernization of the Printing industry, the predominant activity that characterizes the area. Since 1894, this neighborhood has been home to a large number of small printing businesses 
dejan una huella sonora, debido a la sutil "sinfonía industrial" que el golpeteo de viejas y nuevas máquinas ofrece al peatón de las 8:00. am a las 6:00. pm. Resultado de dos años de investigación, el artículo desarrolla una propuesta teórica a través de la definición del concepto territorio sonoro posteriormente validado en el estudio de caso. Apuesta por un enfoque interdisciplinar que involucra la opinión de la comunidad y acude a metodologías que combinan el análisis morfológico del espacio con el registro, mediciones de audio y la escucha del paisaje expresado en cartografías.

PALABRAS CLAVE: TERRITORIO; PAISAJE SONORO; CALIDAD AMBIENTAL; INDUSTRIA GRÁFICA; COLOMBIA.

Recibido: 07-01-2016

Aceptado: 03-10-2016

* El artículo se enmarca en el proyecto “El sonido en el espacio urbano como patrimonio cultural: cartografías digitales para la preservación de la memoria sonora-espacial de la industria de las artes gráficas en el barrio San Nicolás (Santiago de Cali, 1894-2013)", de la Universidad Icesi de Cali, con financiación de Colciencias.

* Colombia. Arquitecto y músico. Doctorando en teoría e historia de la arquitectura por la UPC de Barcelona. Profesor de los departamentos de Diseño y de Artes y Humanidades, de la Universidad Icesi de Cali. Correo electrónico: jllorca1@yahoo.com that left a footprint of sound generated by the subtle "industrial symphony" performed by the drumming of old and new machines and offered to passersby from 8:00 am to 6:00 pm. This three-year research project develops a theoretical proposal through the definition of the sound territory concept, which is then validated through a case study. Based on an interdisciplinary approach, this study addresses the opinions of the community and uses methodologies that combine morphological analysis with the recording, sound measurement and hearing of landscapes which are mapped.

\section{KEYWORDS: TERRITORY, SOUNDSCAPE, ENVIRONMENTAL QUALITY, PRINTING INDUSTRY, COLOMBIA}

Received: 07-01-2016

Accepted: 03-10-2016

* This paper is part of the project entitled "Sound within the Urban Space as Cultural Heritage: Digital Maps for Preserving the Sound-Spatial Memory of the Printing Industry in San Nicolás (Santiago, Cali, 1894-2013)", Icesi University, Cali; funded by Colciencias.

* Colombia. Architect and musician. PhD in Theory and History of Architecture, UPC, Barcelona. Professor, Departments of Design and Arts and Humanities, Icesi University, Cali. Email: jllorca1@yahoo.com. 


\section{Introducción}

El diseño urbano, más allá de valorar la relación costo-beneficio en términos financieros, debe tener en cuenta que aquello que el sujeto percibe tiene efectos fundamentales y profundos sobre el bienestar. En ese sentido, entendemos el sonido como un elemento ambiental fundamental del paisaje urbano que funge de mediador entre el territorio y la sensación, por tanto los análisis que se hagan con miras a intervenir el espacio urbano, deberían investigar el fenómeno sonoro en sus múltiples dimensiones. Con todo, los estudios tradicionales se limitan a hacer diagnósticos cuantitativos de ruido, ignorando otras dimensiones del contexto que incluyan lo subjetivo. Una nueva sensibilidad comporta la historicidad tanto como los vínculos afectivos que se tejen con el ambiente hasta el punto de incluso, establecer valoraciones patrimoniales con lo intangible.

El artículo presenta los resultados de una investigación y pretende hacer una contribución a las iniciativas que buscan entender las complejas dimensiones que conforman la impresión sensible (término de Kevin Lynch) de un espacio, por medio de metodologías basadas en la interdisciplinariedad. En palabras de Lynch, tales "sensaciones configuran la calidad de los lugares y [...] esta calidad afecta nuestro bienestar inmediato, nuestros actos,

\section{Introduction}

Apart from evaluating cost-benefit relationships from a financial perspective, urban design should understand that the perception of its subjects has a critical and deep impact on welfare. In this sense, sound is regarded as a key environmental factor within urban landscape, acting as a mediator between territory and sensation; therefore, studies focused on the reinvention of urban spaces should explore the sound phenomenon in its multiple dimensions. However, traditional approaches are limited to the elaboration of quantitative noise analyses, ignoring other dimensions associated with subjectivity. The emergence of a new sensitivity may influence historicity and the emotional attachment to the environment to the point of establishing a heritage valuation of the intangible.

Thispaperpresentstheresults of researchandseeks to support the initiatives aimed at understanding the complex dimensions underlying the sensitive impression (a term coined by Kevin Lynch) of space through interdisciplinary methodologies. According to Lynch, "sensations determine the quality of places and [...] such a quality affects our immediate welfare, actions, feelings 
nuestros sentimientos y nuestra comprensión"1. Bajo estos criterios durante dos años un grupo de arquitectos, sociólogos, historiadores, antropólogos y artistas, desarrollaron un trabajo de conceptualización y posterior puesta en marcha de las estrategias diseñadas para indagar el paisaje sonoro del barrio San Nicolás.

Partiendo de la interdisciplinariedad del equipo, la investigación abordó distintos frentes con enfoques cualitativos y cuantitativos que se ajustaban a los perfiles de cada integrante. Para contextualizar el oficio de las artes gráficas desde 1894, año en que llegó la primera máquina, se realizaron indagaciones de archivo que ayudaron a construir una cartografía de la ocupación del espacio. La información se fortaleció con el análisis urbanístico y arquitectónico del sector desde lo espacial e histórico. Por otra parte, y ya en función del estado actual del barrio, se realizó una revisión teórica que permitiera relacionar lo morfológico con lo perceptual e indagar la interacción entre el sonido, el espacio y la sociedad. El diseño de la metodología buscó desde el trabajo de campo, articular lo teórico contrastando las conclusiones de los investigadores con lo que manifestaban los habitantes sobre su barrio. Los resultados se recogen en el sitio www.cartofonias.org

1 Lynch, 1992, p. 20. and understanding." Based on these criteria, a group of architects, sociologists, historians, anthropologists and artists conducted a two-year study to conceptualize and implement different strategies designed to explore the soundscape of San Nicolás.

In interdisciplinary terms, this research addressed different dimensions through qualitative and quantitative approaches tailored to the field of expertise of each team member. A literature review was then carried out to contextualize the development of printing arts since 1894 -when the first printing machine was brought to the area- and map the use of space. This information was complemented by an urban-architectural analysis of the area according to a spatial-historical perspective. On the other hand, and focusing on the current state of the neighborhood, a theoretical review was conducted to relate morphological and perceptual aspects and explore the interaction among sound, space and society. The design of this methodology relied on fieldwork to build a theoretical basis and contrast expert findings with the opinions of local residents about their neighborhood. These results can be found at www.cartofonias.org.

1 Lynch, 1992, p. 20. 


\section{0jocentrismo}

La cultura occidental ha cimentado la mayoría de su conocimiento en lo visual debido quizá, a la potencialidad de representación analógica de lo que vemos por medios gráficos. La capacidad de capturar, o fijar lo sonoro se consiguió miles de años después, su esencia efímera apenas si podía ser recordada, descrita o nombrada y hasta representada (las partituras), pero difícilmente fijada.

La supremacía de lo visual ha sido exaltada de muchas maneras, pero sobresale el libro de Berger, Modos de ver de 1972 en el que dictamina, en su primera página, la hegemonía de la visión como sentido: "La vista es la que establece nuestro lugar en el mundo circundante"2. Sin embargo en los últimos años esta manera de pensar ha comenzado a ser revaluada al determinarse la importancia de los otros sentidos. Toop cuestiona el enfoque de Berger argumentando que, dada la orientación frontal de la mirada, la vista es el menos envolvente de los sentidos. "El oído, el olfato, el tacto, la termorrecepción, la propiocepción [...] pueden proveer una respuesta más integral"3.

Debido a esto, la creación de objetos se ha inclinado hacia la satisfacción del ojo, dejando en segundo plano el papel acústico que juegan los diseños.

2 Berger, 2000, p. 13.

3 Toop, 2013, p. 52.

\section{Ocularcentrism}

In the Western world knowledge has been mostly based on visual aspects; this may be due to our capacity to represent analogically what we are observing through graphic means. The ability to capture or retain sound stimuli was achieved thousands of years later; its momentary essence was barely remembered, described, repeated, represented (music scores) but difficult to retain.

Visual supremacy has been praised in many ways; however, special attention should be given to John Berger's Ways of Seeing (1972), which on its first page refers to the hegemony of vision by stating: "Sight determines our place in the surrounding world ${ }^{2}$." Nevertheless, this thought has recently been challenged given the importance attributed to the other senses. David Topp has criticized the approach proposed by Berger by arguing that, given the frontal position of eyes, sight is not as capable as the other senses to interpret the surrounding environment. "Hearing, smell, touch, thermoreception, proprioception [...] may provide a more comprehensive response ${ }^{3}$."

\footnotetext{
2 Berger, 2000, p. 13.

3 Toop, 2013, p. 52.
} 
La predisposición a lo visual es notoria a escalas arquitectónicas y urbanas, donde la incidencia de los volúmenes en el paisaje sonoro es inapelable. Una fachada plana de gran superficie, hecha de un material sonoro-reflectante, tendrá repercusión en la propagación de los sonidos que se le proyectan. Por el contrario, la aparición de vegetación o materiales y/o formas absorbentes puede disminuir el impacto acústico de su entorno. Con todo, el diseño ha realizado una enorme investigación y desarrollo a la acústica de auditorios, se establecen precisos cálculos de las reflexiones de las ondas y la absorción de los materiales con el fin de conseguir espacios confortables para la escucha. Al ser espacios controlados son más fáciles de diseñar pues las variables están definidas, sin embargo la situación que experimentamos en una sala de conciertos posiblemente represente menos del $1 \%$ del tiempo de nuestras vidas. El 99\% restante lo pasamos en espacios que difícilmente se han planeado teniendo en cuenta la interacción entre los objetos, el sonido y nuestra escucha.

Según Augoyard, la investigación ambiental en la arquitectura y el urbanismo presenta dos deficiencias. La primera, estar basada en el conocimiento físico y la segunda, que la aplicación de sus conocimientos se lleva a cabo en formas arquitectónicas y situaciones urbanas precisas, olvidando ocuparse del confort de la cotidianidad ${ }^{4}$. La valoración

4 Augoyard, 2002.
Therefore, the creation of objects has been oriented towards the satisfaction of sight, overshadowing the sound properties of design. The interest in the visual dimension can be easily noticed at the architectural and urban levels, where the effect of volume on the soundscape cannot be denied. A large, flat façade made of sound reflecting materials will affect the propagation of sound. By contrast, the presence of vegetation or absorbing materials may reduce the acoustic impact within surrounding areas. However, there has been a significant amount of research and development in the field of auditorium acoustics; precise calculations have been done for wave reflection and material absorption coefficients in order to achieve proper hearing conditions. These controlled spaces are easy to design as they are based on previously defined variables; however, the time spent in concert halls represent less than one percent of our experiences. The rest of the time is spent in spaces that are not designed to harmonize the interaction among objects, sound and our listening abilities.

According to Augoyard, environmental research on architecture and urban development has two weak points. The first is a focus on physical knowledge and the second has to do with its 
cultural del sonido tampoco ha recibido atención, pues en las políticas públicas se le reduce a la connotación negativa de ruido y en entornos laborales se determina su efecto en términos de salud ocupacional. Como reivindica José Luis Carles, es necesario darle al sonido cotidiano la importancia que merece en sus dimensiones comunicacionales y emocionales. "El concepto de ecología acústica descansa sobre la relación que mantienen las personas con su entorno acústico, planteando por ejemplo, si dicha relación es equilibrada o no, si facilita la integración del individuo dentro de la comunidad o si resulta ajena e insostenible"5.

Paisaje, espacio y territorio ((sonoro)) El nuevo Plan de Ordenamiento Territorial de Cali, ha previsto intervenciones significativas sobre el costado este del barrio San Nicolás. También, la paulatina transformación en las dinámicas socio-económicas, por la modernización de las máquinas de imprenta y la disminución en la impresión en papel en pro de lo electrónico, apuntan a cambiar aspectos culturales y ambientales que incluyen al paisaje sonoro. En ese sentido el diseño urbano que tenga en cuenta el paisaje en todas sus dimensiones, puede contribuir para que las necesarias transformaciones no tengan impactos negativos en aspectos

5 Carles, 2007. implementation, which pays exclusive attention to specific architectural forms and urban contexts, disregarding everyday comfort ${ }^{4}$. Likewise, the cultural value of sound has also been ignored; this is due because public policies associate this dimension with the negative connotation of noise and, within the labor sphere, sound is related to workplace issues. As José Luis Carles argues, there is a need to give everyday sound the importance it deserves in communication and emotional terms. "The acoustic ecology concept is based on the relationship that exists between people and their acoustic environment; then it is suggested whether such a relationship is balanced or unbalanced in nature, or whether it makes it easier for people to become part of a community or it is uncomfortable and unsustainable in time ${ }^{5}$."

\section{((Sound)) Landscape, Space and Territory}

The new Land Use Plan for the City of Cali includes significant modifications to the eastern area of San Nicolás. Likewise, the gradual

4 Augoyard, 2002.

5 Carles, 2007. 
sensibles de la cultura de una comunidad, dando pie a la gentrificación.

"Todo lo que vemos, o que nuestra visión alcanza es el paisaje. Este puede definirse como el dominio de lo visible, lo que la vista abarca. No solo está formado por volúmenes, sino también por colores, movimientos, olores, sonidos"6. Así describe el geógrafo Milton Santos el paisaje, ayudando a revitalizar la pintoresca y contemplativa imagen romántica del landscape. La idea de un paisaje animado y dinamizado por una sensorialidad más amplia rompe el marco bidimensional de la representación tradicional y permite entenderlo como un sistema de complejas relaciones surgidas de la interacción entre el entorno y nuestros sentidos, incluyendo nuestra presencia.

La particularización y definición del sonido como elemento del paisaje y campo de estudio, fue formulada por el compositor Raymond Murray Schafer quien, a principio de los años setenta, fundó en Canadá el World Soundscape Project (WSP) y, con un grupo de colegas, propuso el estudio del entorno sonoro desarrollando el término soundscape, conocido en español como "paisaje sonoro". Se trata, en otras palabras, de un segmento del ambiente sonoro que, acotado desde la escucha consciente, convertimos en objeto de atención. Al registro en audio de dicho ambiente con fines estéticos o

6 Santos, 1996, p. 59. transformation of socioeconomic dynamics derived from the modernization of printing machines, the decrease in hard-copy printing and the increase in electronic-based production has also led to the modification of cultural and environmental aspects -including soundscape. In this sense, an urban design that comprehensively addresses the dimensions of landscape may absorb the negative impacts of these transformations on key aspects of culture, thus giving rise to the phenomenon of gentrification.

"Everything we see, or everything we have within our visual range is associated with the landscape. The latter can be referred to as the visual domain, which is the spatial array available to observation. Landscape is not only composed of volumes but also of colors, movements, smells and sounds.". This is the description of landscape made by Milton Santos, who attempts to revitalize the picturesque and romantic nature of these spaces. The idea of an animated and dynamic landscape that is greatly influenced by a broader sensorial perception breaks the traditional bi-dimensional representation and enables us to understand it as a system composed of complex relationships generated by

6 Santos, 1996, p. 59.

ARTICLE: Soundscape and territory. The case of San Nicolás, Cali, Colombia/ Joaquín Llorca 
documentales, también se le conoce como paisaje sonoro.

La iniciativa canadiense propició la aparición de otros conceptos como la ecología acústica (el estudio del sonido en relación con la vida y la sociedad) y el diseño acústico, una labor en la que, según Schafer, deben participar desde los ciudadanos hasta compositores, arquitectos, sociólogos o psicólogos. Esta manera de entender el diseño tiene inspiración en la Bauhaus al proponer una integración interdisciplinar entre lo científico y lo estético ${ }^{7}$. Lo novedoso radica en extender el diseño de lo acústico y lo sonoro más allá de los auditorios o de las bandas sonoras cinematográficas para ocuparse de nuestro hábitat. Coincide con los estudios sobre el ambiente y paisaje urbanos que Southworth $^{8}$ y Lynch ${ }^{9}$ realizaban desde el urbanismo.

En la actualidad algunos diseños acústicos urbanos no se limitan a diagnosticar o prever el impacto de la arquitectura, sino que intervienen el espacio. En algunas ocasiones con medidas paliativas, ubicando fuentes de agua que enmascaran el sonido del tráfico, pero también con actuaciones más sutiles que, sin sumar energía acústica al ruido, buscan "colorear" o distraer la atención de los ciudadanos. Es el caso de las instalaciones sonoras que aprovechando atributos de los lugares, como

7 Schafer, 1994, p. 205.

8 Southworth, 1969

9 Banerjee y Southworth, 2002. the interaction between the environment and our senses, including our presence.

The identification and definition of sound as an element of landscape and as a field of study was suggested by composer Raymond Murray Schafer who, in the early 1970s, founded the World Soundscape Project (WSP) in Canada. With a group of colleagues, he proposed the study of the sound environment by coining the term soundscape. In other words, this is a segment of the sound environment which, from a conscious listening perspective, becomes the center of our attention. The audio recording of this environment for esthetic or documentation purposes is also referred to as soundscape.

This Canadian initiative led to the emergence of other concepts such as acoustic ecology (the study of sound in relation to life and society) and acoustic design which, according to Schafer, should involve the participation of all individuals, from residents to composers, architects, sociologists or psychologists. This approach draws inspiration from the Bauhaus as it proposes an interdisciplinary convergence between scientific and esthetic spheres. What

7 Schafer, 1994, p. 205. 
el viento, sonidos de la naturaleza o audios tenues, proporcionan equilibrio al ambiente. Se trata pues de medidas más sostenibles que abordan los problemas con soluciones extraídas del paisaje local.

\section{Espacio}

Encontrar nuevas herramientas para el diseño arquitectónico y urbano que apoyen el interés por lo sensible implica aceptar una redefinición de la noción de espacio. Aunque en la arquitectura y el urbanismo el espacio tenga hoy un papel fundamental, su introducción como concepto data del siglo XIX con los aportes de Riegl y Schmarsow, entre otros.

En las últimas décadas el espacio, entendido tradicionalmente como constructo, geométrico y abstracto, se ha transformado gracias a la contribución de Foucault, Lefebvre, Santos, Harvey y Soja, entre otros pensadores sociales que impulsaron el llamado spatial turn. El espacio se considera ahora un régimen que incluye lo físico y lo social, "como un conjunto indisoluble de sistemas de objetos y sistemas de acciones [en el que] podemos reconocer sus categorías analíticas internas. Entre ellas están el paisaje, la configuración territorial, la división is new is the expansion of acoustic and sound design beyond auditoriums or scores to our habitats. There is also a coincidence with the studies on urban environments and landscapes conducted by Southworth ${ }^{8}$ and Lynch ${ }^{9}$.

Today some urban acoustic designs are not limited to diagnosing or preventing the impact of architecture as they are also able to modify space. Some of these interventions include mitigating measures such as the construction of water fountains, which are intended to conceal traffic noise, or more subtle initiatives aimed at "bringing life" to the city or distracting the attention of residents. The latter is the case of the sound installations that bring balance to the environment through the use of wind and natural or low sounds. These sustainable measures address specific issues through the provision of solutions modeled after local landscapes.

\section{Space}

Finding new tools for the promotion of a more sensitive approach within an architectural and urban design context implies accepting the

\section{Southworth, 1969.}

Lynch, 2002. 
territorial del trabajo, el espacio producido o productivo, las rugosidades y las formas-contenido"10. El espacio es una unidad relacional en la que Santos subraya, por un lado, lo indisociable de los objetos naturales y sociales "y por otro, la vida que los llena y anima, la sociedad en movimiento"11. Una sociedad que resuena añadiremos, pues vida es acción, y todo movimiento es sonido y todo espacio es sonoro.

\section{Territorio}

Como una instancia más particular del espacio, la noción de "territorio" encierra un concepto en constante redefinición que involucra una triple dimensión: jurídica, simbólica y económica. No obstante, encontramos vínculos con la idea aristotélica de "lugar" (topos) caracterizada por entender el espacio como un contenedor concreto y empírico, definido y articulado con un sujeto. Es pues la complejidad de relaciones que implica, lo que valida el uso de territorio como categoría adecuada para analizar un espacio con gran riqueza de tensiones como el barrio San Nicolás.

Las tensiones, como afirma Echeverri, ayudan a definir el territorio

10 Santos, 2000, p. 19.

11 Santos, 1996, p. 28. redefinition of the space concept. Though such a notion plays a key role within the architecture and urban domains, it was first introduced as a concept back in the XIX century by Riegl and Schmarsow, among others.

In recent decades, the space concept - which has traditionally been understood as a geometric and abstract construct- has been modified through the contributions of Foucault, Lefebvre, Santos, Harvey and Soja, among other thinkers who promoted the so-called spatial-turn. Today space is regarded as a regime that includes both the physical and social dimensions "as an indissoluble set of objects and actions that enables us to identify its different internal analytical categories. Some of these include the landscape, territorial configuration, the division of labor, the produced and productive space, roughness and the form-content relationship ${ }^{10}$." According to Santos, space is a relational unit marked by the indissolubility of natural and social objects and the "life breath into them, the changing society ${ }^{11}$." Since life is associated with actions, movement with sound and every space operates within the sound dimension, it is safe to say that society is resonant in nature.

\footnotetext{
10 Santos, 2000, p. 19.

11 Santos, 1996, p. 28.
} 
como un proceso histórico de apropiación de un espacio dotado de recursos naturales que forman ecosistemas singulares que determinan formas particulares de aprovechamiento y de estructuras económico productivas. Sobre esta base se construyen redes sociodemográficas, redes institucionales y economías particulares. Los procesos de construcción del territorio establecen una tradición y una cultura sobre las cuales se soporta una identidad y una territorialidad ${ }^{12}$.

A esta definición, que apunta a lo rural, añadiríamos una variable sensorial si aceptamos que el ambiente es parte integral del espacio. Como parte del ambiente, el sonido es un mediador que modula las relaciones entre el hombre y la producción de su entorno llegando a resignificarlo.

\section{Sono-topo}

Las referencias teóricas sobre la intersección entre sonido y espacio (aparte de la física) nos llevan al glosario de Truax y su concepto de "espacio acústico" que se refiere al área en que se escucha un paisaje sonoro ${ }^{13}$. Esta definición, un tanto escueta, adquiere un matiz nuevo con la "biofonía", término que se aplica a entornos naturales sin presencia

\footnotetext{
12 Echeverri, 2011, p. 14.

13 Truax, 1999.
}

20 revista invi 32(89) : 9-59, mayo de 2017

\section{Territory}

As a particular element of space, the notion of "territory" refers to a constant redefinition associated with legal, symbolic and economic aspects. However, there are some linkages with the Aristotelian concept of "place" (topos), which regards space as a concrete, empirical container that is defined and associated with a subject. Therefore, the emergence of complex relationships justifies the use of the concept of territory as the proper category to analyze a tension-rich space such as San Nicolás.

In the words of Echeverri, tensions help to define territories

through a historic process of appropriation of spaces provided with natural resources that create unique ecosystems, which, in turn, determine particular forms of benefit and economic-productive structures. This is the basis upon which sociodemographic, institutional and economic networks are constructed. The processes of the construction of a territory establish a tradition and culture that lay the foundations for the development of identity and territoriality ${ }^{12}$."

12 Echeverri, 2011, p. 14. 
humana. El compositor Bernard Krause acuñó el vocablo y formuló la "hipótesis del nicho" teoría que plantea que en ecosistemas no alterados las especies mantienen un equilibrio en sus voces, o expresiones sonoras al ocupar diferentes frecuencias en el espectro sin enmascaramientos para que cada voz pueda entenderse, aunque suenen todas al tiempo ${ }^{14}$.

La hipótesis del nicho defiende una armoniosa adecuación entre espacio y población natural que recuerda la clasificación de Murray Schafer para los paisajes sonoros urbanos. Por un lado están los de alta fidelidad (hi-fi) paisajes equilibrados en los que es más fácil reconocer los eventos sonoros y su ubicación dentro del espacio acústico y por el otro los de baja fidelidad (lo-fi), donde el horizonte audible es poco discernible, pues la sumatoria de sonidos es recargada ${ }^{15}$. La inteligibilidad de un entorno sonoro indudablemente contribuye a un paisaje cultural en el que los habitantes pueden establecer relaciones más permanentes y estrechas con el hábitat. Encontramos aquí un vínculo con Lynch cuando resalta la importancia de la "legibilidad" de los espacios urbanos y la define como

la facilidad con que pueden reconocerse y organizarse sus partes en una pauta coherente. Del mismo modo que esta página impresa, si es legible, puede ser aprehendida visualmente como una pauta conexa de símbolos

14 Krause, 1993, p. 8.

15 Schafer, 1994, p. 272.
The above rural-oriented definition should be complemented with a sensorial variable, on the understanding that environment is an integral component of space. As an element of environment, sound acts as the mediator between humankind and the production of their environment leading to a change in its meaning.

\section{Sono-Topo}

Theoretical references of the convergence between the sound and space spheres lead us to Truax and his concept of "acoustic space", which refers to the area where soundscapes are heard ${ }^{13}$. This brief definition acquires a new sense with the inclusion of the "biophony" domain, the latter a term applied to natural environments with no human presence. This concept was coined by composer Bernard Krause, who also elaborated the "niche hypothesis" - a theory in which each species (within unaltered ecosystems) maintain their own, balanced voices or sound expressions by using different bandwidths so their voices are not masked, thus enabling intelligibility despite the multiple occurrence of sounds ${ }^{14}$."

\footnotetext{
13 Truax, 1999.

14 Krause, 1993, p. 8.
} 
reconocibles, una ciudad legible sería aquella cuyos distritos, sitios sobresalientes o sendas son identificables fácilmente y se agrupan, también fácilmente, en una pauta global ${ }^{16}$.

Murray Schafer suele ser juzgado por dar énfasis a la ecología en detrimento de un enfoque más etológico, lo cual se interpreta como una reducción de los conceptos de lo-fi y hi-fi a una dicotomía moral entre ruido y sonido bueno. Consideramos más apropiado entender su propuesta como una adecuación del concepto de legibilidad visual de Lynch a la escucha del paisaje sonoro, es decir, un equilibrio en la composición del paisaje. El equilibrio es el criterio a la hora de mezclar los diferentes instrumentos de una pieza musical, ya sea en vivo o en estudio, no en vano Schafer considera el paisaje sonoro una composición musical sin principio ni final que suena todo el tiempo y en la que nosotros somos los compositores. Entornos sonoros desbalanceados (paisajes o música) son muestra de relaciones de poder donde ciertos sonidos resaltan por alguna razón de fuerza. En el barrio San Nicolás los vendedores callejeros de discos compactos se anuncian tratando de sobresalir ocupando pequeños territorios con el volumen de sus

16

Lynch, 1998, p.11.
This hypothesis, which stresses the harmonious adaptation between space and a given natural population, resembles the Murray Schafer classification for urban landscapes. On the one hand, there are hi-fi, balanced soundscapes that enable the identification of sound events and their location within the acoustic space; on the other hand, there are lo-fi soundscapes, where the audible horizon is difficult to identify as the result of excessive sounds ${ }^{15}$. There is no doubt that the intelligibility of a sound environment contributes to the consolidation of a cultural landscape where inhabitants are able to establish longer and closer relationships with their habitats. The latter is related to Lynch and the importance of the "legibility" of urban spaces, which is defined as

The ease with which its parts can be recognized and can be organized into a coherent pattern. Just as this printed page, if it is legible, can be visually grasped as a related pattern of recognizable symbols, so a legible city would be one whose districts or landmarks or pathways are easily identifiable and are easily grouped into an over-all pattern ${ }^{16}$.

\footnotetext{
15 Schafer, 1994, p. 272.

16 Lynch, 1998, p.11.
}

ARTICLE: Soundscape and territory. The case of San Nicolás, Cali, Colombia/ Joaquín Llorca 
reproductores de audio ${ }^{17}$. El ruido, la política y las ciudades -apunta Keizer- maduraron juntos ${ }^{18}$.

En la actualidad, el interés por el ambiente sonoro urbano desde la investigación y la práctica ha aumentado considerablemente logrando integrar saberes diferentes que van desde la arquitectura y el urbanismo, hasta la física, la psicología y la sociología $^{19}$. El arquitecto Jean Gehl, preocupado por la calidad del espacio urbano, destaca la importancia de poder hablar y escuchar este. Su ejemplo es Venecia, una ciudad libre de tráfico en la que escuchamos "pasos, risas, trozos de conversaciones, cantos que salen de ventanas abiertas y otros sonidos de la vida de las ciudades". Conversar y escuchar el sonido de la actividad humana son cualidades importantes ${ }^{20}$. Estas preocupaciones se vienen traduciendo en trabajos que incluyen herramientas cuantitativas y cualitativas para analizar espacios específicos como las investigaciones de Brigitte Schulte-Fortkamp ${ }^{21}$, en ciudades italianas y alemanas o de Carles y Palmese en España ${ }^{22}$.

17 Para una aproximación al ruido desde sus dimensiones políticas, culturales y económicas ver Keizer, 2010.

18 Keizer, 2010, p. 47

19 Para un estado del arte sobre los estudios del ambiente sonoro urbano ver Kang, 2007.

20 Gehl, 2010, p. 152.

21 Asdrubali, 2014

22 Carles, sf.
Murray Schafer is often criticized for focusing more on ecology than on ethology; this can be interpreted as a situation where the lo-fi and hi-fi concepts are reduced to a moral dichotomy between noise and benign sounds. Such a proposal should be understood as an adaptation of the visual legibility concept developed by Lynch to the hearing of soundscapes, that is to say, a balance in the composition of landscape. In this case, balance refers to the criteria used to combine the different instruments of a musical piece, either played live or recorded in a studio; it is with good reason, then, that Schafer regards soundscapes as endless musical compositions created by us. Unbalanced sound environments (landscapes or music) are examples of power relationships where certain sounds prevail by the use of force. In San Nicolás, street vendors selling CDs try to stand out from competitors by occupying small territories through the loud sound coming from their audio players ${ }^{17}$.

17 For an approach to noise from political, cultural and economic perspectives, see Keizer, 2010. 


\section{Objetos sonoros en el territorio}

Antes de abordar el concepto de territorio sonoro aquí propuesto, es preciso definir los elementos que conforman dicho espacio acústico. Por un lado, el contenedor, es decir el paisaje sonoro, y por otro el contenido, que para fines del presente texto serán los objetos sonoros.

La idea de objeto sonoro surge del compositor francés Pierre Schaeffer (1910-1995) quien otorgó a todos los sonidos un estatus estético positivo, incorporándolos al arte desde lo que llamó "música concreta". Esta operación redefinió el ruido y democratizó el papel del sonido en la música, pues dio cabida a sonoridades diferentes a las de los instrumentos tradicionales ${ }^{23}$. Así como un objeto no es basura de antemano, sino que adquiere esa cualidad en relación con su contexto y uso, un sonido no es ruido de antemano sino que lo es cuando no significa nada positivo a la escucha. Siguiendo la idea de Schaeffer, se puede afirmar que el paisaje urbano no estaría compuesto de ruido a secas, sino de la expresión de personas, artefactos, oficios, rituales, espacios, épocas y todo tipo de

23 Schaeffer, 2003.
As Keizer points out, noise, policies and cities evolved together ${ }^{18}$.

Today, the phenomenon of the urban sound environment has drawn significant academic research attention from different disciplines ranging from architecture and urban development to physics, psychology and sociology ${ }^{19}$. Architect Jean Gehl, concerned with the quality of the urban space, highlights the importance of talking and hearing this dimension. The author uses the traffic-free city of Venice as example; here, you can hear "different steps, laughter, fragments of conversations, songs coming out of windows and other city sounds. Talking and hearing the sounds of human activities are important qualities ${ }^{20}$. These concerns are transformed into studies intended to analyze specific spaces according to quantitative and qualitative methods; this is the case of research conducted by Brigitte SchulteFortkamp ${ }^{21}$ in Italian and German cities and Carles and Palmese ${ }^{22}$ in Spain.

\footnotetext{
18 Keizer, 2010, p. 47.

19 For updated studies on the urban sound environment, see Kang, 2007.

20 Gehl, 2010, p. 152.

21 Asdrubali, 2014.

22 Carles, sf.
} 
signos acústicos de nuestra sociedad que existen a partir de la interacción del estímulo físico con la arquitectura, la naturaleza y quienes escuchan. Es muy importante entender que el objeto sonoro no es la fuente que produce el sonido, sino el sonido mismo, en tanto establece relaciones significativas con un sujeto y una sociedad.

\section{Territorio sonoro}

El sonido se integra al espacio como una de las capas de los diferentes sustratos simultáneos que conforman la totalidad del ambiente de un lugar. Afirma Noé García que "de la misma manera que le ocurre al espacio, el sonido también está hecho de tramas heterogéneas, de curvaturas y pliegues, y adopta sentidos que se solapan continuamente"24. Estas palabras traducen el fenómeno sonoro a una útil dimensión morfológica.

El concepto de territorio sonoro aquí propuesto, tiene una instancia morfológica que refiere a un sistema de relaciones sono-espaciales esenciales para la adaptación de los habitantes al medio. Tal sistema está formado por un conjunto espacial delimitado e interconectado por nodos y flujos sonoros de características similares con cierta periodicidad. Los nodos de estas redes están conformados

24 García, 2005, p. 15.

\section{Sound Objects in the Territory}

Before addressing the sound territory concept, it is worth defining the elements composing this acoustic space. On the one hand there is the container -the soundscape- and on the other hand there is the content which, for the purposes of this research, will be referred to as sound objects.

The sound object concept was developed by French composer Pierre Schaeffer (1910-1995), who assigned a positive esthetic status to all senses, incorporating them into arts from the so-called "concrete music" perspective. Such a conception redefined the notion of noise and democratized the role played by sound within the musical context as it welcomed sounds other than those produced by traditional instruments ${ }^{23}$. Just as an item cannot be immediately regarded as disposable unless it is previously used and contextualized, sound cannot be immediately regarded as noise unless it has an effect on hearing. In this way, it can be assumed that the urban landscape is not composed of noise, but of the expressions of people, devices, jobs, rituals, spaces, time and all kind of acoustic signs common to our society -which are generated

23 Schaeffer, 2003. 
por objetos sonoros que con su presencia identifican un espacio.

Debido al carácter "metabólico" de lo acústico, y a la interacción dinámica entre el hombre y su medio ambiente, los territorios sonoros son periódicos, mutables y están determinados por flujos diversos. Entre el día y la noche, los límites de un territorio sonoro pueden variar; entre un día de la semana y otro pueden también modificarse, desdibujarse o redefinirse. Sin embargo, a pesar de cierta elasticidad, existen patrones que permiten establecer el arraigo y delimitar con claridad la triple relación fono-crono-tópica.

La definición de un territorio sonoro cumple dos condiciones: una morfológica, que es relativa a la estructura formal y otra acústica, que comprende la composición sonora del lugar.

La morfológica se refiere a estructuras que se pueden asimilar a espacios topológicos en los cuales entran en juego características como la proximidad, la consistencia, densidad o textura, la conectividad, etc. En la condición acústica la conformación se da por una relación entre los objetos sonoros a partir de sus cualidades físicas como la amplitud, frecuencia y timbre.

Dentro de la condición morfológica encontramos territorios sonoros de tipo central, como cuando las campanas de una iglesia convocan una comunidad. Son marcas sonoras con carácter efímero from the interaction between physical stimuli and architecture, nature and hearers. Therefore it is important to understand that a sound object is not a source of sound but sound itself as it establishes significant relationships between people and society.

\section{Sound Territory}

Sound is integrated into space as one of the different layers composing the environment. In the words of Noé Garcia, "as in the case of space, sound is also made of heterogeneous segments, curvatures, folds and adopts continuously overlapping senses ${ }^{24}$." These words explain the sound phenomenon from a morphological perspective.

The sound territory concept explored in this research has a morphological dimension associated with a system of sound-spatial relationships, the latter being essential for the adaptation of people to the environment. This system is composed of a spatial area that is delimited and interconnected through multiple nodes and periodic sounds with similar characteristics. These nodes are in turn composed of sound objects that create spaces.

24 García, 2005, p. 15. 
y centrípeto. Su inclusión dentro del territorio se concreta por la escucha del objeto sonoro que relaciona a unos individuos en un espacio. Se trata de un espacio topológicamente jerárquico en el que el flujo sonoro viaja en un solo sentido. La emergencia del objeto sonoro condiciona temporalmente la escucha, al fijar el oído en un evento que sobresale del fondo.

Además de la conformación central, los territorios también pueden estar integrados por múltiples objetos sonoros que ocupan el espacio sin necesidad de un faro o nodo central. Esta disposición se asemeja a una red de topología en malla en la que los diferentes nodos se distribuyen con suficiente densidad para que la persistencia del sonido pueda ordenar el territorio. Definiremos dos clases de territorios según su densidad: en ensamble y homogéneos.

Si la densidad de los nodos es media, o sea que la escucha de los objetos sonoros permite determinar su localización, nos encontramos ante un territorio que funciona como un ensamble en el que los elementos sobresalen del fondo sonoro de manera intermitente. Estos territorios son más comunes en entornos urbanos en los que se han agrupado actividades afines con manifestaciones acústicas similares, que proporcionan una identidad rítmica al lugar.

Si la densidad es alta, es decir, que muchos objetos sonoros llenan el espacio en una mezcla que crea
Given the "metabolic" characteristics of the acoustic dimension and the dynamic interaction between humans and their environment, sound territories are periodic in nature, transformable and determined by different types of flows. The limits of a sound territory may vary whether it is day or night; these boundaries can also be modified, became blurred or redefined from one day to another. However, despite being elastic in nature, there are certain patterns that enable the emergence and definition of a triple chronotopo-phonic relationship.

Sound territories have to meet two conditions: a morphologic one, which is associated to their formal structure and the acoustic one, which refers to the sound composition of a given place.

The morphologic condition deals with structures that can be assimilated into topological spaces where characteristics such as proximity, consistency, density or texture, connectivity, etc. come into play. On the other hand, the second acoustic condition is associated with the relationship among sound objects according to physical features such as amplitude, frequency and tone.

The first condition includes a type of sound territory referred to as central-e.g. the ringing of church bells to summon people to worship. These 
un continuo poco poroso, estaremos ante una estructura que no presenta referencias sonoras puntuales, por tanto conforma un espacio homogéneo. Por ejemplo el paisaje sonoro de un ecosistema natural en el que el territorio es definido de forma densa y coral, ya que el sonido producido por cada una de las especies contribuye a la formación de un conjunto acústico que da identidad al espacio donde coexiste su población. La bioacústica estudia los ecosistemas, incluyendo el sonido, sin embargo en ecosistemas humanos, como el espacio urbano, es un campo apenas abordado. Miguel Alonso, propone aplicar el modelo bioacústico a la realidad antropológica de la ciudad y hablar de "sociofonía", que según él es "un término más apropiado en tanto en cuanto ataca el análisis desde un punto de vista relacional, tanto comunicativo como metacomunicativo. Con él pasan a un primer plano el eje contextual y, evidentemente, el sistémico sin centrarse específicamente más que en las formas sonoras que toma la sociabilidad"25.

Pero la dimensión formal no es suficiente, un territorio sonoro solo existe en la medida que quienes le habitan confieran significado a la relación entre el sonido y el espacio. Esta "hermandad" o identificación de un grupo de personas desde la escucha se define con un ejemplo histórico. Desde el siglo XV en Londres se identificaba a los cockney, habitantes de estrato popular del East End (que

25 Alonso, 2005, p. 38. are ephemeral and centripetal sound marks. Their incorporation into the territory is defined by hearing the sound object that establishes relationships among individuals within a given space. This is a hierarchical space where sound travels in one direction. In this case the hearing function is conditioned by the emergence of the sound object since all attention is given to the notorious event that is taking place at that moment.

Apart from the description above, there are territories composed of multiple sound objects that use the available space despite not having a central element. Such a configuration is related to a net-like topology in which the dense distribution of nodes enables a persistent sound to cover a specific territory. Two classes of differently dense territories fall within this category: connecting and homogeneous territories.

If these nodes are moderately distributed, which is when the hearing of sound objects enables their localization, the area containing them is classified as a connecting territory where elements stand out from the sound space on an intermittent basis. These territories are commonly found in urban environments where acoustic activities take place, thus giving a rhythmic identity to the area.

ARTICLE: Soundscape and territory. The case of San Nicolás, Cali, Colombia/ Joaquín Llorca 
tienen un acento y dialecto particular), como todos aquellos que residieran en una zona donde fuera posible escuchar las campanas de St. Mary-le-Bow.

En algunas poblaciones de Colombia las estaciones de bomberos hacen sonar sus sirenas a las $12 \mathrm{del}$ mediodía. La práctica comenzó para comprobar el funcionamiento del artefacto. Con el tiempo se convirtió en una marca que propicia un vínculo espacio-temporal y congrega a quienes la escuchan otorgándole sentidos como la pausa para comer o como indicador de calamidades. Estos sonidos centrales como faros, conforman territorios periódicos que dentro de su radio de influencia citan por unos segundos a una comunidad agrupada por un nicho aural.

\section{Contexto}

La ciudad de Cali (2.369.829 habitantes) comenzó desde hace 50 años un proceso de expansión debido a la urbanizaron de terrenos deshabitados. Además de la llegada de miles de migrantes, gran parte de la población empezó a moverse hacia la periferia abandonando los sectores centrales. El centro histórico se fue debilitando hasta el punto de perder su carácter simbólico. La ciudad actualmente está elongada de norte a sur y cuenta con diversas
On the other hand, if nodes are densely distributed -which is when a large number of sound objects occupy a given space and create an almost flat continuum-, the structure containing them has no specific sound references, thus being classified as a homogeneous territory. An example of this definition would be the soundscape of a natural ecosystem where territory is defined by dense and chorus-like forms; the latter is due because the sound produced by each element creates an acoustic dimension that gives an identity to the area. This is where bioacoustics comes into play. Such a discipline, a branch of science, studies the ecosystem, including sound; however, within the context of human ecosystems -such as the urban space- this domain has been little explored. Miguel Alonso suggests applying the bioacoustic model to the anthropologic reality of the city and discussing the "sociophony" concept which, according to the author, "is the proper term as it addresses this analysis from a relational perspective -both at the communication and meta-communication levels ${ }^{25}$."

However, this formal dimension is not enough; sound territories only emerge when residents recognize the importance of the sound-space relationship. This "brotherhood" or sense of

25 Alonso, 2005, p. 38. 
centralidades. Al mismo tiempo, la proliferación de centros comerciales cerrados fue sustituyendo el espacio público, mientras que el antiguo centro se ha visto invadido por el comercio informal. Algunos barrios tradicionales de estratificación popular, donde se mezclaba la vivienda con actividades comerciales y de pequeña industria, continuaron un proceso de deterioro físico, tan solo atenuado por una gran vida comercial que sigue generando mucho empleo.

La iglesia de San Nicolás, que dio nombre al barrio, fue construida en el siglo XVII. El barrio es adyacente, por un lado, a la plaza fundacional de Cali y por otro, a la primera zona industrial de la ciudad, marcada por la línea del ferrocarril (inactivo desde 1991). Desde sus inicios acogió a las clases populares y fue el barrio de abajo (bayano) con suelo de tierra a diferencia de los barrios altos (altozano) empedrados. Hoy en día sobresale una actividad industrial y comercial que por historia y presencia es referente. Se trata de las artes gráficas, un oficio con antecedentes importantes en el barrio pues en 1894 Manuel Carvajal, compró una máquina tipográfica y la llevó a su casa de San Nicolás. Poco después se imprimieron allí algunos de los más importantes diarios de la región, comenzando así la historia de Carvajal \& Cía., una de las empresas gráficas que llegó a ser líder del sector en Latinoamérica. ownership is illustrated by an historic example. Since the XV century, the city of London has been associated with the Cockneys (an East End working-class group with a particular accent and dialect) and all those inhabiting the area where the bells of St. Mary-le-Bow Church were heard.

In some parts of Colombia, local fire stations activate their sirens right at midday. Such a practice was initially intended to check the proper functioning of the sound device. As time went by this exercise became a tradition that enabled the emergence of a space-time relationship that people currently associate with lunch time or the occurrence of disasters. These central sounds create periodic territories where people meet for a short period of time.

\section{Context}

Fifty years ago, the city of Cali (2,369,829 inhabitants) began to experience a process of expansion resulting from the urbanization of uninhabited zones. Apart from the massive arrival of migrants, most of the population moved 
FIGURA 1. DENSIDAD DE IMPRENTAS EN EL BARRIO, 2015

FIGURE 1. DENSITY OF PRINTING FIRMS, 2015

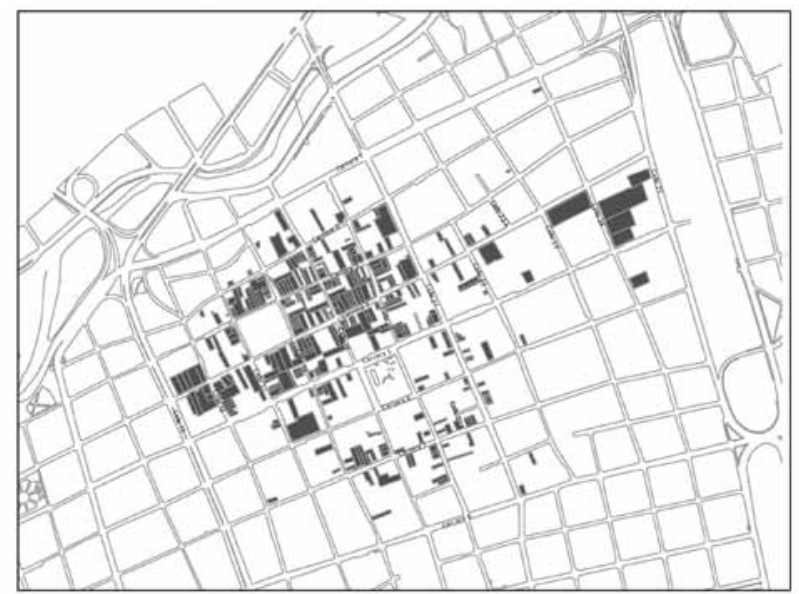

Fuente: Acervo documental de la investigación.

Source: Document archive

Actualmente (2015) 527 empresas, según censo propio, en su mayoría pequeñas, trabajan las artes gráficas en un área no mayor a 20 manzanas, es decir, unos $1.200 \mathrm{~m}^{2}$. El sonido marca el pulso de este pequeño territorio que despierta antes de las 8:00 a.m. y comienza a cerrar sus negocios a eso de las 6:00 p.m. La señal de inicio podría ser la marca oficial de la iglesia, que con sus campanas anuncia la misa de 7:00 a.m. e inaugura el movimiento. Sin embargo sonidos menos celestiales comienzan a entonar su sinfonía industrial, en la medida que el sol avanza. to peri-urban areas, abandoning the central area of the city. The historic center was weakened to the point of losing its symbolic nature. Today the city is stretched north to south and has different central areas. At the same time, public spaces were overshadowed by the proliferation of enclosed shopping centers and the old central area was invaded by informal trade. Some traditional and popular neighborhoods, which combine housing, trade and small-scale industry activities, are currently experiencing a physical deterioration process that has been mildly tempered by a strong commercial production which is still a major source of employment.

The San Nicolás Church, which gave its name to the neighborhood, was built in the XVII century. This area is located next to the main square of Cali and the first industrial district that is delimited by a railway line (inactive since 1991.) Unlike stone-paved neighborhoods located in uptown areas, San Nicolás -located in a low, unpaved area-has always been home to the popular/working classes. Today there is important industrial and commercial activity in the area, which has gained recognition because of its history and presence. Most notably is the case of the printing arts industry, an activity that is particularly important for the history of the neighborhood. In 1894, Manuel Carvajal 


\section{FIGURA 2. BARRIO SAN NICOLÁS \\ FIGURE 2. SAN NICOLÁS}

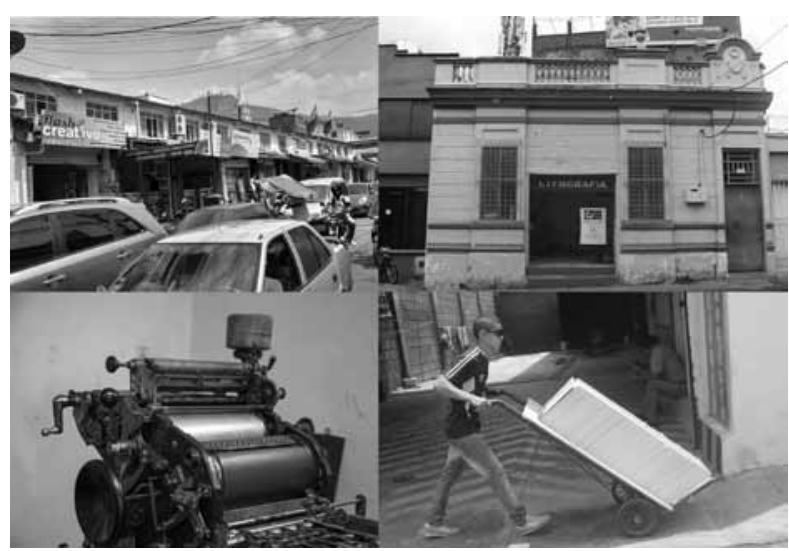

Fuente: Acervo documental de la investigación.

Source: Document archive

La historia del barrio se ha ido reconstruyendo a partir de documentos escritos y fotografías, sin embargo estos documentos son mudos, y del ambiente en el que se desenvolvió la vida durante muchos años no se tienen datos. Quizá sea la lenta transformación del paisaje sonoro la que disimula su dimensión histórica y nos dificulta pensar en las grandes diferencias que hubo en el ambiente del pasado. Antes de la llegada de la electricidad a Cali, el 26 de octubre de 1910, no existía el continuo fondo de frecuencias bajas entre los 100 y bought a printing machine and took it to his home located in San Nicolás. Soon after, some of the most important newspapers of the region were printed there; this was the beginning of Carvajal \& cía, a once-leading printing firm in the region.

According to a census conducted by this research in 2015, there were 527 small printing businesses operating in an area no larger than $1,200 \mathrm{~m}^{2}$. Sound governs the activities carried out within this small territory that wakes up before 8:00 am and closes at about 6:00 pm. The starting signal is issued at 7:00 am by church bells calling to prayer. However, less heavenly and more industrial-like sounds began to emerge as the day goes on.

The history of the neighborhood has been reconstructed through written documents and pictures; however, these data do not provide sound information and there are no recordings of the environment. It is possible that the slow transformation of soundscape dissimulates its historical dimension and makes it difficult for us to think of the great differences that may have existed in the past. Prior to the arrival of electricity on October 26, 1910, the continuous, 
$130 \mathrm{~Hz}$, presente, pero inadvertido, y que hoy está incorporado a nuestras vidas por obra de los refrigeradores, aires acondicionados, transformadores eléctricos y otros motores. Los habitantes del centro de Cali estaban más expuestos a sonidos de animales domésticos, campanas y pregones callejeros. La llegada de la electricidad desencadenó unas nuevas dinámicas sociales que comenzaron a transformar el paisaje sonoro. El alumbrado del Parque Caicedo permitió prolongar las retretas dominicales hasta las 9:00 p.m. cambiando "la manera de concebir y vivir la noche y el día, el espacio y el tiempo, el ritmo de la vida, y las relaciones interpersonales [..." $]^{\prime 26}$.

También en 1910 se inauguró el tranvía a vapor que bordeaba el barrio por sus costados sur y este. En 1913 llegan los automóviles para acompañar las motos Horex que ya rugían por la ciudad ${ }^{27}$. Estas apariciones modernas comenzaban a genera prácticas que aportaban su voz al nuevo paisaje sonoro. En 1914 se hizo necesario reglamentar los automóviles existentes, exigiéndoles llevar una placa para detectar a quienes alteraban el orden público. El decreto $n^{\circ} 11$ regulaba su uso, pues algunos jóvenes en las noches "se dedican a correr por la población, especialmente en la parte baja, cantando canciones torpes, abusando del licor, escandalizando y perturbando a los vecinos que no pueden dormir

26 Vásquez, 2001, p. 69.

27 Ibíd., p. 176. low-frequency tone -ranging from 100 to 130 $\mathrm{Hz}$-did not exist. Today such a sound is part of our lives through refrigerators, air conditioning systems, electrical transformers and other types of engines. The inhabitants of central Cali were commonly exposed to the sounds produced by domestic animals, bells and town criers. The arrival of electricity generated new social dynamics that transformed the soundscape. The lighting system installed on Parque Caicedo extended Sunday retreats until 9:00 pm, thus changing the "way of thinking of day and night, space and time, the pace of life and interpersonal relationships $[\ldots]^{26}$."

Likewise, the year 1910 witnessed the launching of the steam-powered tramway that ran through the south and east sides of the neighborhood. The first cars were introduced in 1913 to join the previously imported Horex motorcycles ${ }^{27}$. These new elements generated practices that introduced new voices into the emerging soundscape. The enactment of Order $n^{\circ} 11$ regulated the use of these vehicles as the result of the reports of young people who "run through the area, especially in the low zones, singing absurd songs, drinking excessive amounts of alcohol, generating chaos

\footnotetext{
26 Vásquez, 2001, p. 69.

27 Ibid., p. 176.
} 
[...]"28. Vemos pues la pertinencia de interrogar los documentos históricos en busca de signos del paisaje sonoro anterior.

\section{Método}

Como se ha expuesto, los territorios sonoros se componen de complejas densidades acústicas formadas por objetos, líneas o recorridos que marcan y ocupan temporalmente el espacio y a su vez trazan límites. Estos bordes y nodos resonantes, crean una invisible, pero audible distribución del espacio que articula o separa zonas. Para precisar los límites y la naturaleza del territorio sonoro en cuestión, el problema ha sido abordado desde varios frentes, aprovechando y reinterpretando metodologías desarrolladas en las últimas décadas. La evaluación urbana iniciada por Lynch y Southworh que logra ligar lo morfológico con lo perceptual, se complementa con los ejercicios de escucha, medición y registro propuestos por la escuela canadiense del WSP que permitieron comprender el paisaje sonoro como un objeto de estudio, categorizándolo.

$28 \quad$ Ibíd., p. 178. and disturbing the sleep of residents $[\ldots]^{28}$." This prompted us to examine historical documents and find evidence of old soundscapes.

\section{Method}

As previously discussed, sound territories are composed of complex acoustic densities generated by objects, lines or trajectories that identify, use and define spaces on a temporary basis. These limits and sound nodes create an invisible, yet audible, distribution of space which unites or divides different areas. This research addresses this issue by recognizing the limits and nature of sound territories and reinterpreting different methodologies developed over the last decades. The urban analysis conducted by Lynch and Southworth, which conciliates morphological and perceptual dimensions, is complemented with hearing, measurement and recording activities proposed by Canadian based group WSP. These exercises enabled us to properly analyze and categorize soundscapes.

$28 \quad$ Ibid., p. 178. 
Por otro lado están los trabajos del laboratorio Cresson de la Escuela de arquitectura de la Universidad de Grenoble donde a finales de los años setenta un grupo de filósofos, sociólogos y arquitectos se plantearon indagar la interacción entre el sonido, el espacio y los habitantes. Su interdisciplinar se apoyó en encuestas, entrevistas, cartografías sociales y escuchas de grabaciones seleccionadas para luego presentarlas a grupos focales y estudiar sus impresiones. La fusión y aprovechamiento selectivo de estas metodologías permite obtener conclusiones formales, perceptivas y simbólicas, que modulan la perspectiva del investigador con el sentir de los que habitan el espacio.

La aplicación de las metodologías trazadas para el estudio del caso tuvo tres fases. La primera para establecer el área del territorio, la segunda para determinar su composición y la tercera para evaluar la percepción que tienen los habitantes sobre su paisaje sonoro.

Un primer recorrido por el barrio, arrojó algunas conjeturas preliminares en las que sobresalen dos actividades que tienen presencia jerárquica en el paisaje sonoro: por un lado la industria gráfica con docenas de imprentas sonando y por otro, la venta de altavoces y música en discos compactos o memorias USB, dos actividades que generan sonidos estridentes en la parte sur. Nuestra investigación se ha centrado en la zona de la industria gráfica, por ser la que articula un espacio con gran historicidad
On the one hand, there are the studies conducted by the Cresson laboratory at the School of Architecture, Grenoble University during the late 1970s, where a group of philosophers, sociologists and architects explored the interaction that existed among sound, space and individuals. This interdisciplinary project was complemented with surveys, interviews, social maps and the hearing of selected recordings that were then used during focus group sessions for further analysis. The fusion and selective use of these methodologies allowed the development of formal, perceptive and symbolic conclusions, enabling researchers to adjust their perspectives to the actual feelings of local residents.

The implementation of these methodologies was divided into three phases. The first deals with the identification of territorial areas; the second has to do with the understanding of their composition; and the third refers to the evaluation of the perception of dwellers about their own soundscapes.

The first exploration of the neighborhood enabled us to make different conjectures, chief among them being two hierarchical activities that take place within soundscapes: on the one hand 
en su actividad económica y por las características del sonido mecánico de las imprentas que dan un color tímbrico propio al sector. El mapa construido a partir del censo realizado ${ }^{29}$, dibuja un área muy concentrada donde se localizan la mayoría de negocios que con sus sonoras máquinas, marca el pulso del sector así como su paisaje sonoro industrial y rítmico.

\section{Morfología del territorio sonoro}

Un territorio sonoro funciona como un mapa dinámico que evidencia los límites y fracturas del espacio. Para establecerlos hay que determinar los cambios significativos en la organización territorial teniendo en cuenta la dimensión sonora. En San Nicolás el territorio generado por la industria gráfica dibuja un perímetro rectangular de 6 por 3 manzanas. Con tres bordes claramente definidos por el sonido del tráfico de sus vías arteria:

a) La calle 15 al costado oeste, b) la calle 21 al costado este y c) la carrera $5^{\mathrm{a}}$ al costado sur, presentan una gran densidad de sonido de tráfico cuya principal composición son resonancias de

29 El conteo arrojó resultados sobre las características de los locales dedicados a las artes gráficas, los servicios ofrecidos, las máquinas usadas y la percepción de los trabajadores sobre el paisaje sonoro del barrio. Para más detalle ver www.cartofonias.org there is the Printing industry and its dozens of sound-generating printing businesses; and on the other hand there is the selling of speakers, CDs and USB flash memories. These two activities produce loud sounds in the southern area of the city. This research focuses on the zone where printing businesses are located; such a choice was mainly based on the historicity and unique sound features of the area. The census data ${ }^{29}$ were used to elaborate a map that identifies a section characterized by the massive presence of printing businesses which, through the sound produced by their machines, define the dynamics and the industrial-rhythmical soundscape of the area.

\section{Morphology of Sound Territories}

Sound territories may serve as dynamic maps showing the limits and fractures within space. In order to identify them, there is a need to pay attention to the sound dimension and the changes experienced by the territory. In San Nicolás,

29 The sampling yielded results on the characteristics of printing businesses, the services they provide, their machines and the perception of workers about the local soundscape. For further details, visit www.cartofonias.org.

ARTICLE: Soundscape and territory. The case of San Nicolás, Cali, Colombia/ Joaquín Llorca 
motores y bocinas, reguladas por el compás de los semáforos. En este caso coincide el borde físico con el sonoro, pues al acercarnos a las vías, el sonido nos anuncia que hay un margen y que rebasarlo significa pasar a otro espacio.

El borde norte es muy diferente, pues no está marcado por una gran vía o barrera físicas, ni por una gran manifestación sonora, sino justamente por su ausencia. Sobre la carrera $2^{\mathrm{a}}$, una vía interior del barrio, es notorio el deterioro de las edificaciones y de los locales, algunos están deshabitados. También hay edificaciones de gran superficie, volcadas al exterior norte del barrio y ajenas al mundo gráfico con grandes fachadas cerradas. En la $2^{\mathrm{a}}$, sobre todo en la parte oeste, se refugian indigentes habitantes de la calle que ocupan parte del solitario espacio con carretas en las que llevan papel y cartón reciclados. Este borde "silencioso", que colinda con un nuevo territorio, está matizado por el esporádico paso de automóviles, diálogos de algunos de los habitantes de la calle y el rodar de las carretas en que cargan lo recogido. Para el visitante esta "calma" es inquietante, pues mantiene la alerta de que algo puede sucederle y que se está adentrando en un territorio ajeno donde el sonido de la multitud no le arropa. Es una alarma silenciosa que traza un borde en un contexto que, por su gran actividad, debería tener un campo sonoro bastante denso y al no ser así conforma una barrera más psicológica que física. the territory generated by the Printing industry covers a rectangular perimeter measuring $6 \times 3$ blocks, with three borders clearly defined by traffic sound:

a) $15^{\text {th }}$ Street, west side; b) $21^{\text {st }}$ Street, east side; and c) $5^{\text {th }}$ Road, south side. These segments show great traffic sound density, which is mainly composed of acoustic resonance generated by running engines and horns and regulated by the rhythm of traffic lights. In this case physical and sound limits converge as the sound produced in these roads separates this area from others. Different is the case of the northern limit, which is characterized by the lack of physical and sound barriers. Upon reaching $2^{\text {nd }}$ Street -an inner roadit is possible to observe the deterioration of partly abandoned buildings and businesses. There are also large northern-oriented buildings unconnected with the Printing industry through their massive closed façades. This street-especially its western part-is home to groups of homeless people who use this abandoned space to park their carts, which are used to carry recycled materials such as paper and cardboard. This "quiet" border, located adjacent to a new territory, is sometimes disrupted by passing vehicles, conversations among local residents 


\section{FIGURA 3. TERRITORIO SONORO}

\section{FIGURE 3. SOUND TERRITORY}

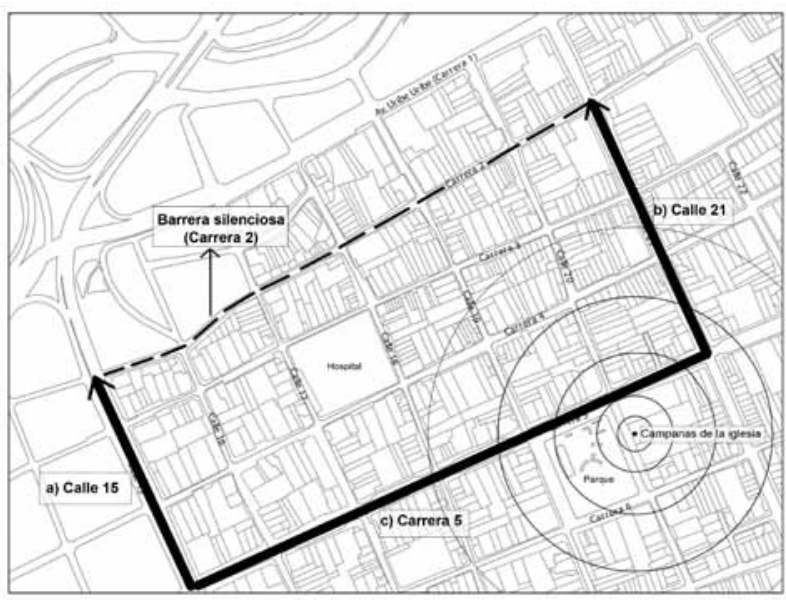

Fuente: Elaboración propia.

Source: Elaborated by the author.

\section{Composición acústica}

Para caracterizar la composición sonora del área, cada miembro del grupo de investigadores se encargó de auscultar una franja horaria desde las 6:30 a.m. hasta las 7:30 p.m. Las escuchas aconsejaron particularizar el estudio a tres calles para profundizar en la composición sonora del barrio. Al tiempo se diseñaron instrumentos para la recolección de la información y posteriormente se hicieron grabaciones y mediciones de la presión sonora en las mismas franjas. and the movement of carts. For visitors, the "quietness" of this area may be regarded as disturbing; as a result, they become alert to potential risks since they are entering into foreign ground where the sound of the crowd does not provide protection. This silent alarm draws a dividing line within a context that was supposed to be noisy in nature, enabling the emergence of psychological rather than physical frontiers.

\section{Acoustic Composition}

In order to characterize the sound composition of the area, each member of the research group was given the task of analyzing a specific time slot from $6: 30$ am to $7: 30 \mathrm{pm}$. The results of this recording exercise prompted this research to focus on three streets to further explore the sound composition of this neighborhood. A series of instruments were designed for data collection purposes and different recordings and measurements were made to determine the sound pressure level during a given time slot.

These streets were selected according to the following criteria: density of printing businesses,

ARTICLE: Soundscape and territory. The case of San Nicolás, Cali, Colombia/ Joaquín Llorca 
Los criterios de selección para las tres calles fueron: la densidad de imprentas, el tráfico vehicular y humano, y la dinámica social. Las calles estudiadas fueron:

Calle 17 entre carreras $5^{\mathrm{a}}$ y $4^{\mathrm{a}}$ : gran densidad de imprentas, mucho tráfico vehicular y humano. Alta actividad comercial (audio 1).

Carrera $4^{a}$ entre calles 18 y 19: una de las principales calles del barrio, Densidad de imprentas media, flujo de personas moderado y poco comercio (audio 2).

Carrera $3^{a}$ entre calles 19 y 20: alta densidad de imprentas, tráfico vehicular moderado. poco flujo de personas y algunas viviendas (audio 3).

AUDIO 1. CALLE 17, MARTES 2 DE SEPTIEMBRE 2014, 13.34 PM.

AUDIO 1. 17TH STREET, TUESDAY, SEPTEMBER 2, 2014, 1:34 PM.

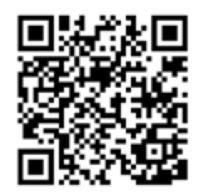

https://www.youtube.com/watch?v=txgFyvXZF_0 human and vehicular traffic and social dynamics. The three selected streets were as follows:

$17^{\text {th }}$ Street - located between $5^{\text {th }}$ and $4^{\text {th }}$ Roads: Large density of printing businesses, significant human and vehicular traffic. High commercial activity (audio recording 1.)

$4^{\text {th }}$ Road -located between $18^{\text {th }}$ and $19^{\text {th }}$ Streets: One of the main streets in the area, average density of printing companies, moderate flow of people and low commercial activity (audio recording 2.)

$3^{\text {rd }}$ Road -located between 19 and 20 Streets: Large density of printing businesses, moderate vehicular traffic, reduced flow of people and presence of some housing units (audio recording 3.)

This time-sampling method was divided into four time slots which, according to previous hearing activities, represent the main transition moments from 7:00 am to 7:00 pm.

- 7:00 am-8:30 am

- 11:00 am-12:30 pm

- $1: 30 \mathrm{pm}-3: 00 \mathrm{pm}$ 
AUDIO 2. CARRERA 4, VIERNES 5 DE SEPTIEMBRE 2014,12.00 AM.

AUDIO 2. 4TH ROAD, FRIDAY, SEPTEMBER 5, 2014, 12:00 AM.

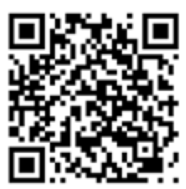

https://www.youtube.com/watch?v=MveLvzG6pkc\&t

\section{AUDI0 3. CARRERA 4, MARTES 23 DE SEPTIEMBRE 2014, 11.30 AM.}

AUDIO 3. 4TH ROAD, TUESDAY, SEPTEMBER 23, 2014, 11:30 AM.

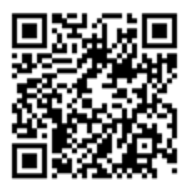

https://www.youtube.com/watch?v=XrY2Ftn-Or8

El muestreo temporal se dividió en cuatro franjas horarias que, según el trabajo previo de escuchas, representaban los principales momentos de transición entre las 7.00 a.m. y las 7:00 p.m.

- 7:00 a.m. - 8:30 a.m.

- 11:00 a.m. - 12:30 p.m.

- $\quad$ 1:30 p.m. - 3:00 p.m.

- $\quad$ 5:30 p.m. - 7:00 p.m.
- $\quad 5: 30 p m-7: 00 ~ p m$

These hearing slots were used for two days (Tuesdays and Fridays), which represent the different commercial dynamics of the area. According to information provided by respondents, Tuesday is regarded as a normal day and Friday is regarded as a hectic day because of the weekend.

The hearing of these three streets enabled the identification of the most repeated sounds. The result was the elaboration of a list containing 16 sound objects and their occurrence frequency. Then, this research paid specific attention to five of the more frequent sounds: the drumming of printing machines; the sound produced by doors and rolling shutters; the sound produced by the carts used by suppliers, recyclers and street vendors; and the music coming out from radio or audio systems that accompany the daily life of a musical neighborhood. The recognition of these notable and easily identifiable sound objects enabled us to acoustically classify this area as a connecting territory. 


\section{TABLA 1. FRECUENCIA DE OBJETOS SONOROS POR CALLE Y FRANJAS HORARIAS}

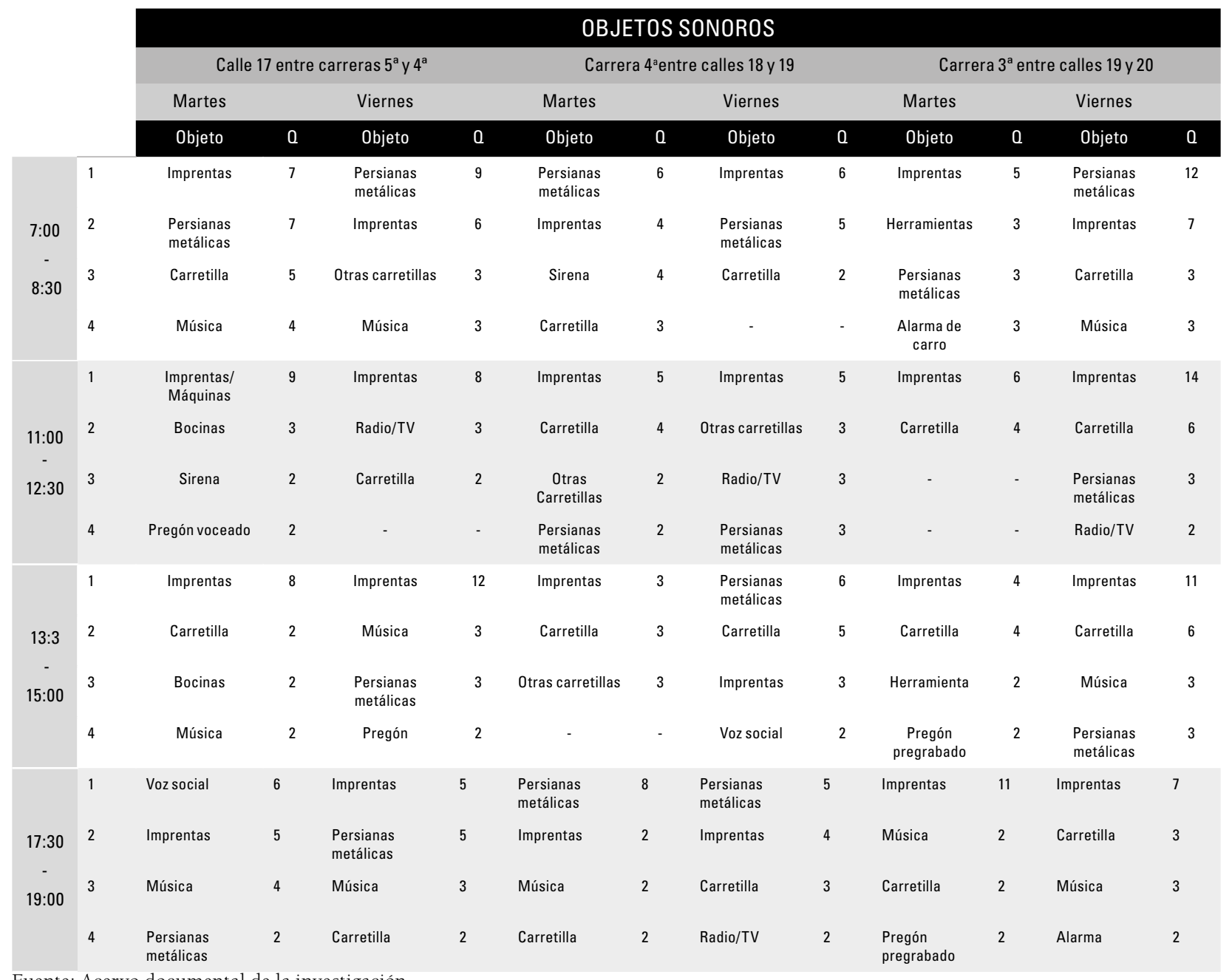

Fuente: Acervo documental de la investigación. 
TABLE 1. FREQUENCY OF SOUND OBJECTS PER STREET AND TIME SLOT

\section{SOUND OBJECTS}

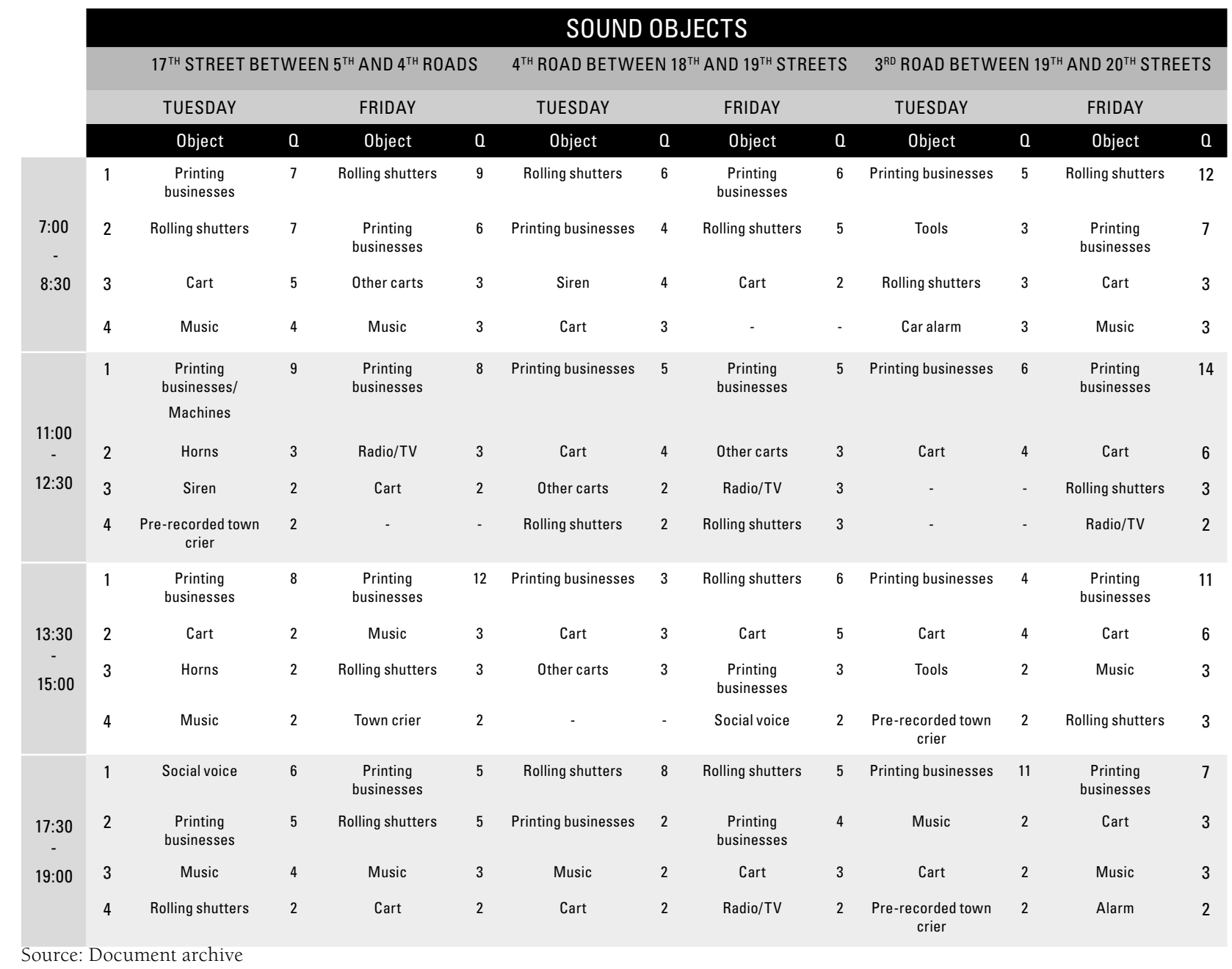


Estas franjas de escucha se replicaron durante dos días de la semana (martes y viernes) que representaban diferentes dinámicas comerciales del barrio. El martes como día corriente y el viernes como día de mucho movimiento, por estar cercano al cierre de semana, según la información que los trabajadores entrevistados aportaron.

Durante las escuchas en las tres calles se consignaron los sonidos que más se repetían. El resultado fue un listado de 16 objetos sonoros con su frecuencia de aparición. La investigación centró su atención en los 5 más frecuentes a saber: el golpeteo de las máquinas de imprenta, el rugido de la puerta o persiana metálica enrollable que cierra los locales, el rodar de las carretillas transportadoras de insumo y las de las carretas de recicladores y vendedores ambulantes. Por último la música que, desde radios y sistemas de audio, acompaña la cotidianidad de un barrio con tradición musical. El reconocimiento de los objetos sonoros sobresalientes y discernibles del fondo, nos permite clasificar el territorio, desde el punto de vista acústico como un ensamble.

\section{Identidad sonora del territorio}

El interés de investigar a través de la escucha, radica en los vínculos que se pueden establecer entre los objetos sonoros relacionados y el rol que,

\section{Territory Sound Identity}

The goal of this research is to explore the different relationships among sound objects and their acoustic role within the sociocultural dynamics of local environments. Given the fact this study was conducted in a traditional area, it is important to define the historicity of sound objects as they are related to the past of the city. The latter justifies their weight within the result section of this research.

It is no surprise, then, that the constant drumming of printing machines was regarded as the main sound object ${ }^{30}$. Printing machines that vary in age and type can be found in these businesses which, given their narrowness and depth, operate with their front doors open-thus spreading the sound they produce. Walking through these streets means moving from one rhythm to another as the result of the different tones emitted by printers. According to operators, the sound produced by these instruments indicates if they are properly functioning or not. As for passers-by, these sounds give an identity to the area.

30 Audio recordings are available at www.cartofonias.org. 
desde su manifestación acústica, juegan dentro de las dinámicas socioculturales del territorio. Ya que el trabajo se ha realizado en un espacio con fuerte tradición para la ciudad, es muy importante determinar la historicidad de sus objetos sonoros, pues los liga al pasado, lo que de alguna manera justifica su aparición en los resultados con un peso propio y no solo como un ítem más en un listado.

El principal objeto sonoro ${ }^{30}$, por número de apariciones, resultó ser sin mucha sorpresa, el golpeteo de las máquinas de imprenta. En los locales se encuentran imprentas de todo tipo y antigüedad. La mayoría tiene poco frente y varían en profundidad, funcionan con las puertas abiertas, lo que permite escuchar el funcionamiento de las máquinas. Recorrer las aceras es pasar de un ritmo a otro acompasados por los diferentes timbres de las máquinas. Los operarios reconocen que el sonido les da información sobre el correcto funcionamiento del aparato y los que transitamos por el barrio sentimos un color local en aquellos sonidos.

Las primeras máquinas que llegaron fueron las tipográficas y aún sobreviven muchas, (el 30\% de los negocios tiene alguna según el censo) sobre todo las Chief y las Heidelberg. Su sonido está compuesto por el de la bomba que empuja la prensa y el contrapunto de la pinza que va pasando el papel. Este robot paquidérmico parece caminar

30 Las grabaciones de la investigación se pueden escuchar en www.cartofonias.org

44 revista invi 32(89) : 9-59, mayo de 2017
Printing presses were the first machines introduced to the area; today a great number of these are still in operation (according to the census conducted by this research, 30 percent of businesses have one of these machines), especially the Chief and Heidelberg models. The sound produced by these instruments is generated by pumping and counterpoint systems. These large machines generate short, deep and long, high-pitched sounds. The arrival of lithographic technology meant the end of the predominance of these instruments which, though not versatile in nature, were transformed into die-cutting machines -thus postposing the end of their life cycle.

The second sound object identified by this research was the sound produced by rolling shutters. Metal carpentry was another activity that benefited from technological breakthroughs as it enabled the exploration of materials other than wood. There are records about metal artisans who operated in Cali back in the 1920s; this is the case of the Hurtado family and its armory and metal carpentry workshop located in the central area of the city ${ }^{31}$. The everyday metallic cracking generated from 7:30am to

31 Vásquez, 2001, p. 88. 
con un corto sonido grave y otro más agudo que se alarga. La llegada de la tecnología litográfica fue relegando estas máquinas que, aunque menos versátiles, se han reinventado como troqueladoras o como numeradoras, resistiéndose a callar definitivamente.

\section{VIDEO 1. TIPOGRÁFICA BRANDTJEN KLUGE CONVERTIDA EN TROQUELADORA.}

\section{VIDEO 1. BRANDTJEN KLUGE PRESS TURNED INTO A DIE-CUTTING MACHINE}

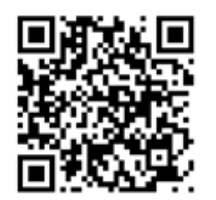

https://www.youtube.com/watch?v=3zenplX2VvM

El segundo objeto sonoro que emergió fue el rugido de la puerta metálica que cierra la gran mayoría de los locales. La carpintería en metal fue otro de los oficios que con los cambios tecnológicos abriría nuevos desarrollos más allá de la madera. Hay noticia de que en los años veinte ya existían en Cali artesanos del hierro como la familia Hurtado que tenía un taller de armería y carpintería metálica en el centro ${ }^{31}$. La concentración de puertas en un área tan pequeña da origen a un objeto sonoro característico, pues cada día cientos de crujidos metálicos 8:00am by the hundreds of doors distributed in such a reduced area creates a unique sound that is only muted on Sundays (Audio 4.)

A significant number of businesses share the same sound dynamics generated at the beginning of the working day. The lifting of iron curtains, which is guided by side rails, is amplified by the space within these businesses and replicated by the nearby walls located across the street -there are no more than $8 m$ between them. Everyone hears the opening of their own and adjacent business.

Carts are also regarded as sound objects. They slowly go through the neighborhood and create sounds in specific streets, thus being acoustically associated with the area. The first of these objects is the rough sound produced by metal carts carrying paper and ink through deteriorated paved roads (Audio 5.) Informal carts are the other sound category included in this section; these hand-made, wooden vehicles are used by street vendors or recyclers who regularly move around the area.

The sound generated by carts carrying paper reveals the dynamics of a collaborative and associative business based on the sharing of

31 Vásquez, 2001, p. 88. 
entre las 7.30 a.m. y las 8.00 a.m. crean una marca que tan solo se enmudece los domingos (audio 4).

\section{AUDIO 4. PERSIANA METÁLICA}

\section{AUDI0 4. ROLLING SHUTTER}

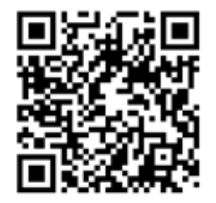

https://www.youtube.com/watch?v=tWgpXO4xCqE

La dinámica sonora del inicio del día suele ser igual para muchos locales. El empujón de los articulados listones férreos, dirigidos por los rieles laterales hacia arriba, encuentra amplificación en esa inmensa caja de resonancia que es el espacio del local y réplica en la cercana pared del frente, pues las calles no superan los 8 metros de ancho. Todos oyen la apertura propia y la del local vecino.

Otros dos objetos sonoros surgieron desde las ruedas de las carretillas y carretas. Su paso por el barrio es pausado e indudablemente resuenan dentro de unas pocas calles, reforzando su pertenencia al lugar. El primero de ellos fue el carrasposo rumor de la carretilla metálica usada para transportar papel y tintas que se trasladan por el deteriorado pavimento del barrio (audio 5). El otro es su versión informal, un variado grupo de vehículos construidos de forma artesanal, normalmente de madera, territory. While some businesses are exclusively focused on printing production, there are other establishments focused on the provision of diecutting, varnishing or cutting services. This is why it is common to observe carts moving from one street to another. The erratic characteristics of the pavements, which have suffered from neglect and intense traffic explain the zigzagging movement of carts, which left a residual noise generated by their hard or soft wheels. Informal carts, known as carretas by local residents, produce different sounds depending on the material their wheels are made of. These vehicles, whose plastic or rubber wheels are attached to metallic wheel bearings, are used to carry fruit, refreshments, ice creams or coffee prior to the beginning of the working day. Another difference between carts and carretas is that the latter, especially those designed to carry paper, produce compound sounds. In this case the cadence of wheels is also accompanied with the tinkling of recipients or tools and recorded or live announcements. This category also includes the sound produced by the hand-made carts used by recyclers who move around the area in search of discarded paper.

Lastly, it comes as no surprise, the inclusion of musical sounds in this list of sound objects. It has been years since phonographs or jukeboxes were used to listen to the music performed by 
usados por vendedores ambulantes o recicladores que recorren también las calles asiduamente.

\section{AUDIO 5. CARRETILLA DE INSUMOS POR LAS CALLES DEL BARRIO.}

\section{AUDIO 5. CART CARRYING SUPPLIES THROUGH LOCAL STREETS}

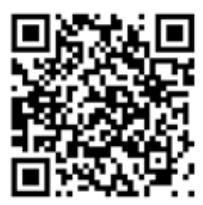

https://www.youtube.com/watch?v=cJkiuawBS6c

El sonido de la carretilla para el papel, da cuenta de la dinámica de un negocio que ha resultado colaborativo y asociativo gracias a compartir territorio. Mientras unos locales imprimen, otros troquelan, otros barnizan y otros cortan. Por ello es habitual el recorrido de los carritos de una calle a otra. El errático suelo, gastado por el intenso tráfico y el deterioro desatendido, es responsable del zigzagueante transitar de las carretillas que con sus ruedas duras o blandas van dejando una estela sonora por las calles. La versión informal de la carretilla es llamada carreta por la gente del barrio, el sonido de las ruedas, que rechinan contra el suelo, es variado por sus materiales. Las hay de balineras metálicas, de ruedas plásticas o neumáticas y sirven para llevar frutas, refrescos, helados o el café a primeras horas de la mañana cuando aún orchestras or singers. Today there are still some establishments relying on this type of musical reproduction; however, most of the music heard on each corner comes from radio, TV or digital mp3 players (Audio 6.)

As expected from a city with a hot climate and a deeply-rooted musical tradition, these sounds are an essential part of the local landscape. The early 1930s witnessed the launching of La Voz del Valle, the first radio station in Cali. This event was followed by the selling of the first radio receivers such as Westinghouse (the US), Philips (the Netherlands) and Blaupunkt (Germany). This list also included the receivers manufactured by Philco, Telefunken, RCA and Emerson ${ }^{32}$. Within less than a decade, the sound produced by these radio receivers became a pivotal part of the local soundscape and society.

San Nicolás also adopted this musical technology, the neighborhood stories of people who collected vinyl records imported from the US gave rise to a culture of bolero, Antillean and Mexican music. This emerging phenomenon also favored the consolidation of leisure spaces, some of which still exist today.

32 Vasquez, 2001, p. 254-255. 
FIGURA 4. FICHA TÉCNICA, CALLE 17, DÍA MARTES

\section{FIGURE 4. DATA SHEET, 17TH STREET, TUESDAY}
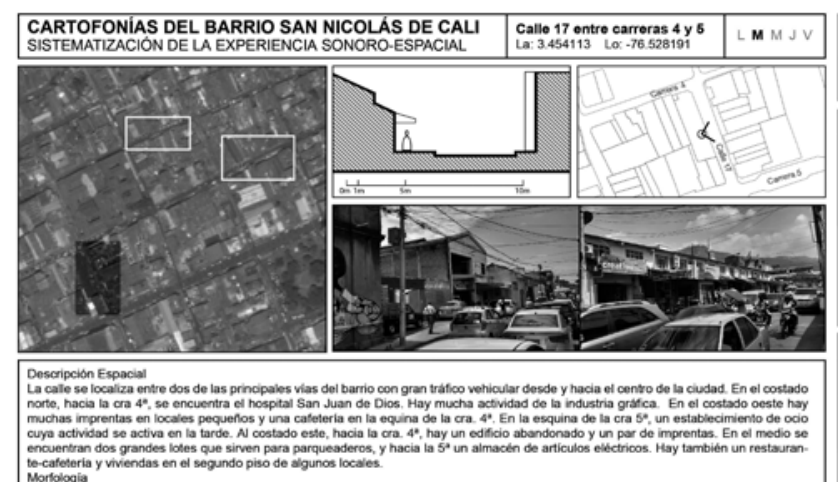
to-cateteria y viviendas en el segundo piso de algunos locales

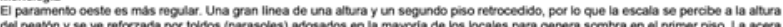

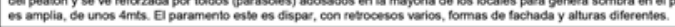

\begin{tabular}{|c|c|c|c|c|}
\hline Bis & Dinámica del Espacio & Material Sonoro & 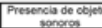 & \\
\hline & 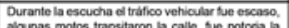 & $\operatorname{los}$ & $=$ & \\
\hline & aparicica & $\begin{array}{l}\text { perstanas } \\
\text { se van er }\end{array}$ & 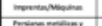 & \\
\hline & $\begin{array}{l}\text { ingo que } \\
\text { veticular }\end{array}$ & $\begin{array}{l}\text { iomata } \\
\text { de las . }\end{array}$ & $=1$ & \\
\hline & $\infty$ & & $=$ & \\
\hline & locales o & & S-mon & \\
\hline & cto & & an & $\therefore$ \\
\hline & motes a & autoon & $\sin$ & \\
\hline & Respect 10 lat & firang & 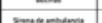 & \\
\hline & & que ile & $n=$ & \\
\hline & pers & & & \\
\hline & 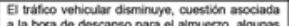 & compu & $a$ & \\
\hline & moto & & 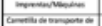 & \\
\hline & 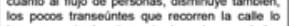 & & $=$ & \\
\hline & & & mis & \\
\hline & & & & \\
\hline & & & $=0$. & \\
\hline & ta & $\begin{array}{l}\text { as ate } \\
\text { sogur }\end{array}$ & nempons & \\
\hline & & $\begin{array}{l}\text { sapo y missica a } \\
\text { conversacianes ? }\end{array}$ & 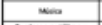 & \\
\hline & 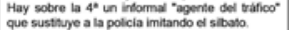 & 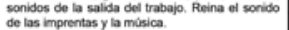 & nome & \\
\hline
\end{tabular}

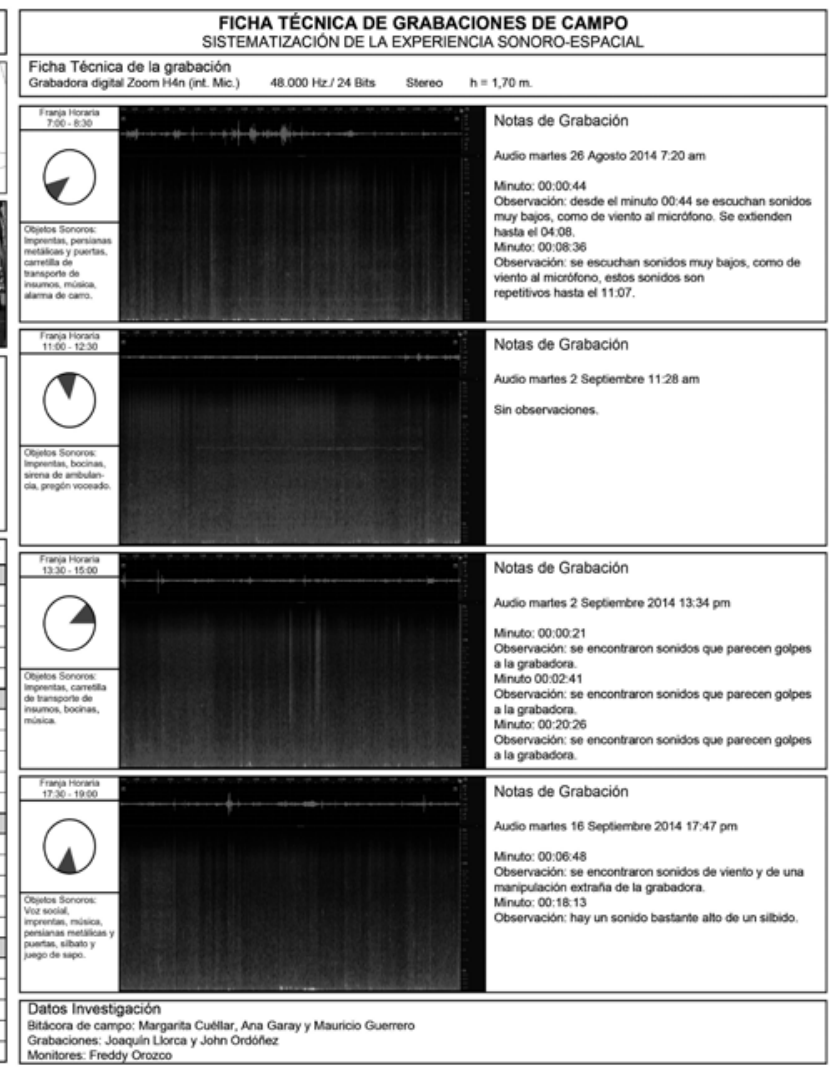

Fuente: Elaboración propia.

Source: Elaborated by the author 
no arranca la jornada laboral. También se diferencia de las carretillas de cargar papel en que su sonido puede ser compuesto. La cadencia de las ruedas frecuentemente está acompañada del tintineo de algún recipiente o utensilios que se tambalean entre la carga y también de un pregón en vivo, o pregrabado, que anuncia el producto que se oferta. En este grupo también rechinan las improvisadas carretas de los recicladores que rondan buscando desechos de papel.

Por último, no es de extrañar que los sonidos musicales fueran el otro objeto sonoro que completó la investigación. Han pasado muchos años desde que orquestas y cantantes sonaban por Victrolas de manivela o las automáticas rockolas de monedas. Hoy en día algún establecimiento conserva sus discos de vinilo, sin embargo la gran mayoría de música que se entona por cada esquina proviene de radios, televisores o reproductores digitales en formato mp3 (audio 6).

\section{AUDIO 6. MÚSICA EN UN CAFÉ 11.30 AM.}

AUDI0 6. MUSIC PLAYED AT A CAFÉ, 11:30 AM.

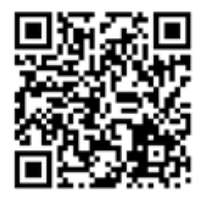

https://www.youtube.com/watch?v=-6KYfvGp8_0
The results of fieldwork were organized in a format that includes graphic and geographic information, spatial and sound descriptions, sound objects, spectrograms and sound pressure measurements.

\section{Sensitive Impression}

In addition to collected audio data, this research evaluated the perception of local dwellers through interviews, the elaboration of maps and focus groups.

Interviews were conducted with 247 printing businesses in order to establish the relationship between operators -who use their working spaces from 8:00 am to 6:00 pm- and the local soundscape. When asked about the most distinctive sound of San Nicolás, 46.15 percent of respondents mentioned the noise produced by printing machines. A large percentage of interviewees also referred to traffic noise.

Four focus groups were conducted with local residents, the owners of printing businesses, the operators of printing businesses and customers in order to identify their respective perceptions 


\section{FIGURA 5. SONIDOS MÁS REPRESENTATIVOS PARA LOS TRABAJADORES SEGÚN LA ENCUESTA}

\section{FIGURE 5. THE MOST REPRESENTATIVE SOUNDS ACCORDING TO OPERATORS}

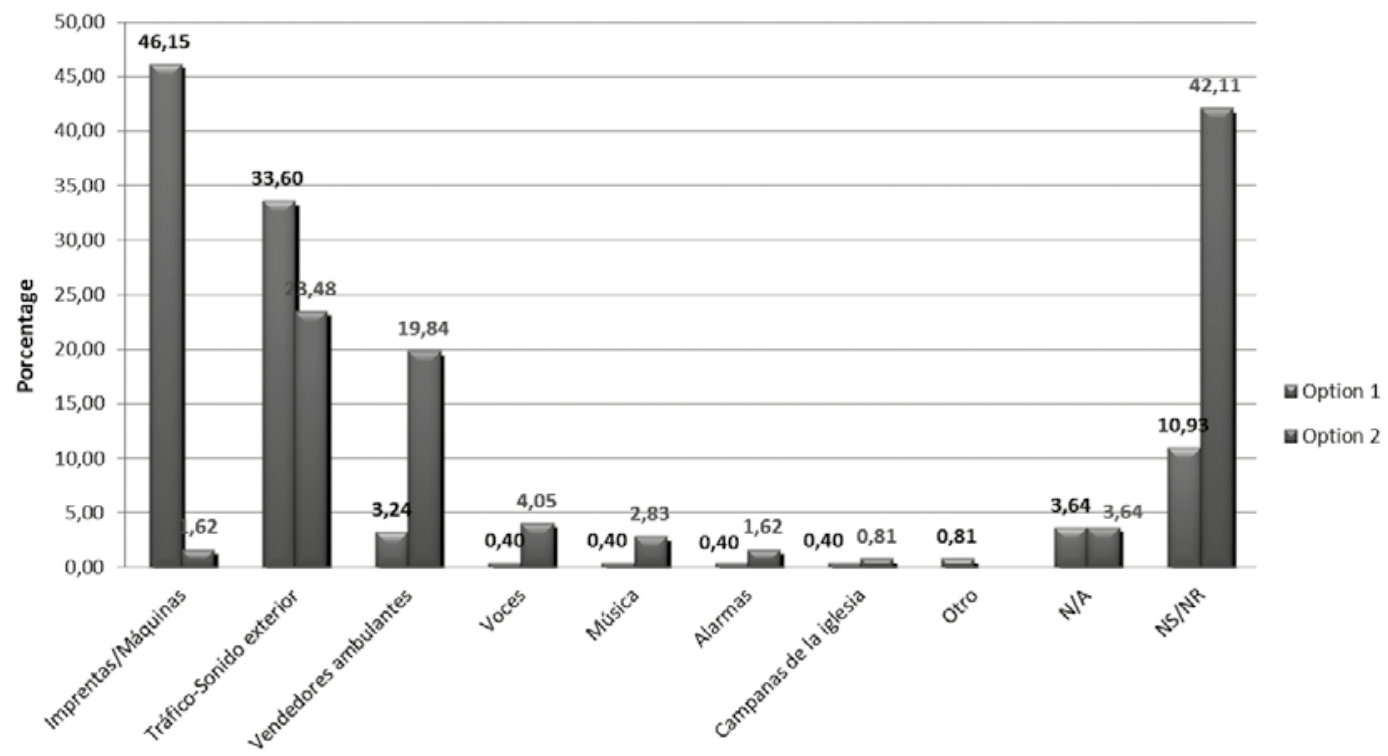

Fuente: Acervo documental de la investigación.

Source: Document archive.

Era de esperarse que en una ciudad de clima cálido con tanta tradición musical, estos sonidos hicieran parte del paisaje. Iniciando la década del treinta se inauguró La Voz del Valle, primera emisora de Cali. Al tiempo se comenzaron a vender los radioreceptores Westinghouse americanos, los Phillips holandeses y los Punto Azul alemanes. También about their neighborhood. These sessions began with an awareness exercise on the environmental issue until reaching a discussion moderated by researchers, who took notes and video recorded each of these meetings. Some of the issues under discussion were the localization of sound objects, the search for significant sounds and the acoustic 
llegaron los Philco, los Telefunken, los RCA y los Emerson $^{32}$. En menos de una década el murmullo de la radio comenzaba a hacer parte importante del paisaje sonoro y de la sociedad caleña.

Un sector popular como San Nicolás, incorporó la tecnología de la música, las historias barriales de legendarios coleccionistas de discos traídos de Estados Unidos nutrieron una cultura alrededor de los boleros, la música antillana y la mexicana. También se consolidaron lugares de ocio alrededor de la música. Algunos aún sobreviven.

Los datos resultantes del trabajo de campo en cada uno de las calles escuchadas, se ordenaron en un formato que reúne información gráfica, geográfica, descripción espacial y sonora, objetos sonoros, espectrogramas y mediciones de presión sonora.

\section{Impresión sensible}

Además de los datos recogidos desde las escuchas, se consultó la percepción de los habitantes por medio de encuestas y cartografías sociales realizadas por grupos focales.

Las encuestas se realizaron en 247 negocios de las artes gráficas para establecer el vínculo que los trabajadores, quienes lo habitan de 8.00 a.m. a 6.00 p.m., tenían con el paisaje sonoro. Al preguntarles

32 Vasquez, 2001, p. 254-255. qualification of the neighborhood according to the elaboration of maps.

Apart from the references to traffic, residents also regarded some sound objects as identifying sounds. Two centralities emerged from the discussions on the old landscape. On the one hand, there are the church bells that indicate the beginning of the day. On the other hand, there are the sirens of fire stations, which, despite being located in a continuous neighborhood, were perceived all middays. One respondent regarded church bells as a current representative sound; this suggests the evocative nature of this sound and indicates that old sound objects, despite apparently being absorbed by urban noise, are still meaningful to some individuals.

Another interesting finding is the importance given to the sound produced by the carts of street vendors, especially at about 7:00 am, which is when they sell coffee. Such a clearly identifiable sound also marks the beginning of the day as it disrupts the quiet morning landscape.

Apart from the recurring complaints against noise, the dialogue established to elaborate the map depicting the local soundscape highlighted a series of positive aspects. One of the most important of these points of view suggests that the traditional San Nicolás Park is an urban 
por el sonido que más relacionan con San Nicolás, un $46,15 \%$ confirmó que efectivamente, las máquinas de imprenta producen el objeto sonoro más importante. Otro gran porcentaje nombró al tráfico.

Los grupos focales se realizaron con cuatro colectivos para averiguar la percepción de: los habitantes del barrio, los dueños de los negocios de artes gráficas, los operadores de las imprentas y los clientes de los servicios de imprenta. Las sesiones comenzaron con una sensibilización sobre el tema ambiental hasta llegar a una conversación colectiva guiada por los investigadores que iban tomando nota y registrando las sesiones en video. Entre los temas abordados estaba la localización de objetos sonoros, la búsqueda de sonidos significativos y la cualificación acústica del barrio a partir de dibujos sobre el mapa.

Además de las referencias al tráfico, algunos habitantes resaltaron como sonidos característicos ciertos objetos sonoros. Dos centralidades emergieron de las conversaciones sobre el paisaje antiguo. Por un lado, las campanas de la iglesia como referente a la hora de marcar el inicio del día. Por otro, la sirena de bomberos, que a pesar de tener su cede en un barrio contiguo, era perceptible cada medio día. Un entrevistado confirmó como sonido representativo actual las campanas, lo cual subraya el carácter evocador del sonido y que antiguos objetos sonoros, por más que parezcan enmascararse entre el rugir de la urbe, siguen teniendo significado para algunos. oasis because, despite being surrounded by busy roads, it offers the possibility to hear birdsongs coming from its trees (Audio 7.)

\section{Decrescendo}

In many cases, soundscape design could turn the city into a less tense, more pleasant and more informative place for those who inhabit it (Michael Southworth ${ }^{33}$.)

San Nicolás is an exceptional place to analyze the relationship that exists between urban spaces and sound since, apart from its tradition, it has an age-old consolidated cluster of printing businesses around the area. The labor of printing operators has changed from the use of old, leadbased materials to the current digital technology (plotters and laser printers.) The identification of a sound territory from a theoretical and empirical perspective reveals an environmental identity that still survives despite the effects of traffic noise. From a theoretical point of view, this territory connects sound objects thanks to their proximity and density. There is a clear and coherent morphology that, according to

33 Southworth, 1969, p. 65. 
Otro interesante hallazgo fue que el sonido de las carretas de vendedores ambulantes también fue significativo, sobre todo alrededor de las 7:00 a.m. cuando comienzan a rodar hacia las esquinas donde venden el café y que se pueden escuchar con claridad como una marca sonora de cada mañana debido al silencioso paisaje matinal.

Aparte de las recurrentes quejas sobre el ruido, el diálogo llevado a cabo con el fin de dibujar un mapa sobre el paisaje sonoro del barrio, resaltó aspectos positivos. El más importante el parque San Nicolás, un espacio con tradición que para muchos puede ser percibido como un oasis, porque a pesar de estar en medio de vías concurridas, entre sus árboles se escucha el canto de algunos pájaros (audio 7).

\section{AUDIO 7. PARQUE SAN NICOLÁS, FEBRERO 6 , VIERNES 16.20 P.M.}

\section{AUDIO 7. SAN NICOLÁS PARK, FRIDAY, FEBRUARY 6, 4:20 PM}

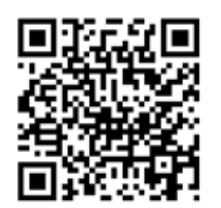

https://www.youtube.com/watch?v=JysB0OiyzMY
Echeverri $^{34}$, is associated with a historical appropriation process that has given rise to productive structures. From a quantitative perspective, the valuation of the sociocultural role played by sound objects enabled us to identify their incorporation into a community associated with the Printing industry. Despite being large in number, the sound produced by printing machines does not affect the local environment as they operate within legally established time limits; on the contrary, they add a subtle rhythmical sound to the area.

The imminent reinvention of the Printing sector, triggered by digital modernization and urban intervention, suggests the need of preserving the memory of a traditional and deeply-rooted activity that relates the housing and labor spheres. The sound territory also reveals a habitat that -apart from having the obligation to improve- should be taken into consideration when implementing urban modifications intended to achieve a more balanced and unique soundscape.

The modification of soundscapes resulting from industrialization processes brought new mechanic sounds that were initially regarded as noise. However, sounds associated with traditional

34 Echeverri, 2011, p. 14. 
FIGURA 6. CARTOGRAFÍA SOCIAL ELABORADA POR HABITANTES DEL BARRIO

\section{FIGURE 6. SOCIAL CARTOGRAPHY ELABORATED BY LOCAL RESIDENTS}

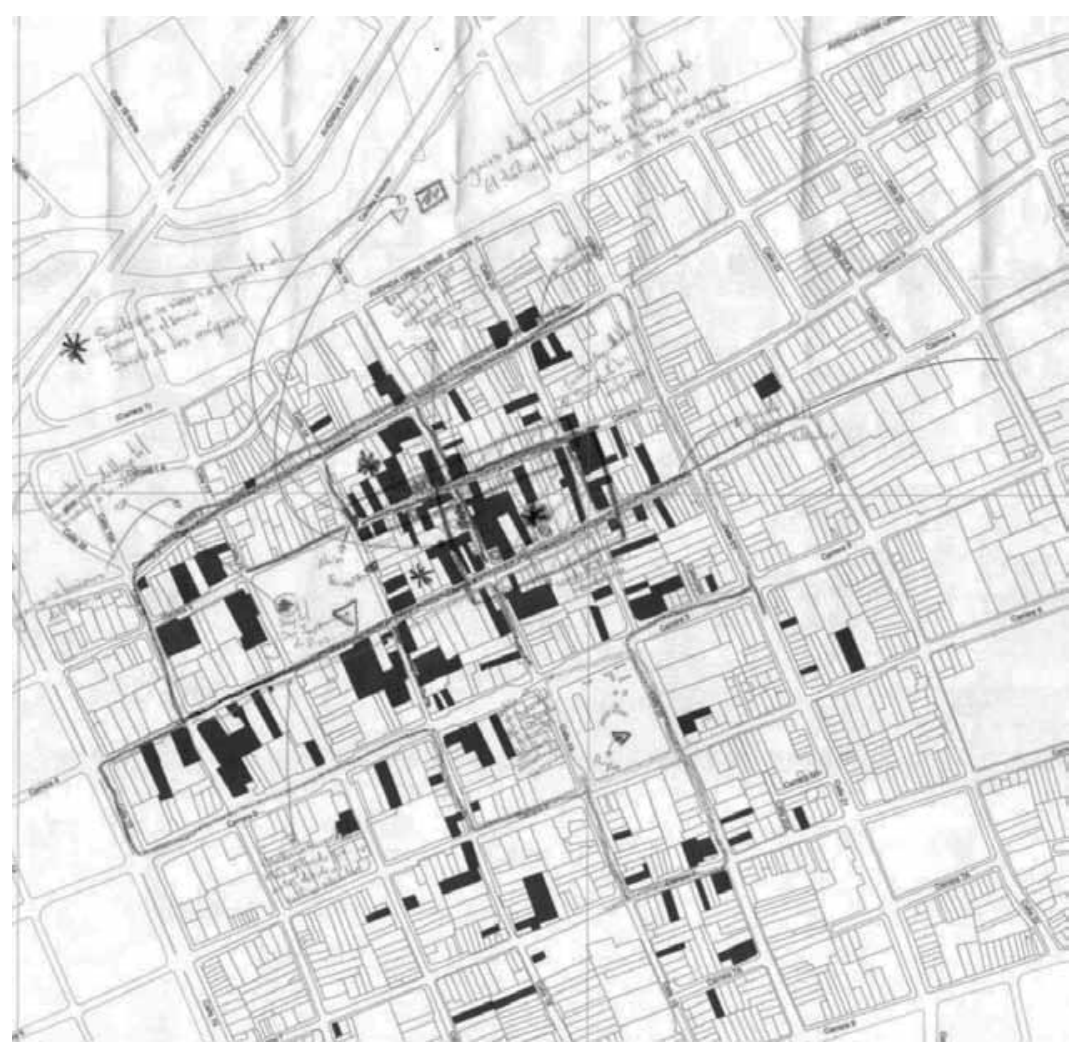

Fuente: Acervo documental de la investigación

Source: Document archive 


\section{Decrescendo}

En muchos casos el diseño del paisaje sonoro por sí solo, podría ser una manera de hacer la ciudad menos tensa, más agradable y más informativa para quienes la habitan. (Michael Southworth) ${ }^{33}$.

San Nicolás es un espacio excepcional para analizar la relación entre espacio urbano y sonido pues, además de su tradición, ha consolidado en más de un siglo de actividad, un cluster alrededor de la imprenta. El trabajo del impresor ha modificado su artesanía desde que la imprenta se hacía con tipos de plomo hasta la actual tecnología digital (plotters e impresoras láser), obvia el complejo oficio y silencia su mecánico funcionamiento. La determinación de un territorio sonoro desde lo teórico y lo empírico revela una identidad ambiental que aun sobrevive entre el sonido del tráfico. Desde lo teórico se ha establecido que el territorio se comporta como un ensamble de objetos sonoros, gracias a la proximidad y densidad de los mismos. Presenta una morfología clara y coherente que, como propone Echeverri ${ }^{34}$, responde a un proceso histórico de apropiación del espacio en el que se han conformado estructuras productivas. Desde el análisis cuantitativo, la valoración del papel sociocultural que juegan los objetos sonoros del territorio permitió descubrir su integración a una comunidad

33 Southworth, 1969, p. 65.

34 Echeverri, 2011, p. 14. and industrial activities were incorporated into a culture that adopted and redefined them, thus becoming part of everyday life. These "noises" do not emerge by themselves within a lo-fi context; depending on their relationship with the environment, they can become part of a balanced landscape that incorporates unique and identifiable sounds. In San Nicolás, printing machines provide the territory with a specific acoustic condition as they contribute their rhythmical sound in a subtle way. In this sense, the sound territory concept proposed here corroborates the "legibility" theory developed by Lynch as sound objects enable the identification of soundscapes. According to our perception and the work conducted with local residents, traffic noise -and not printing machines-affects and relegates landscapes to a lo-fi category.

It is also worth noting that the interdisciplinary methodologies developed for the purposes of this research enhanced the understanding of the area under review. The exchange among experts, from a historic, spatial and sensitive perspective, laid the foundations for the elaboration of proper land management tools. This study identified the need to keep working with local residents in order to fully understand their relationships with their habitat; such a finding demands the 
agrupada alrededor de la industria gráfica. El sonido que producen las imprentas, a pesar de su gran número, no agrede el ambiente del lugar si se atiene a los horarios legales y por el contrario añade un sutil ritmo al ambiente.

Ante la inminente reinvención del sector gráfico por la modernización digital y ante las intervenciones urbanas que auguran cambios en el barrio, es recomendable preservar la memoria de un oficio de comprobada tradición y arraigo, articulando la convivencia del oficio con la vivienda. El territorio sonoro da cuenta de un hábitat que, si bien puede y debe mejorar, ha de ser tenido en cuenta para realizar intervenciones positivas en pro de un paisaje sonoro más equilibrado y que mantenga rasgos identitarios.

El cambio en el paisaje sonoro propiciado por la industrialización trajo a las ciudades nuevas sonoridades mecánicas que en un principio han sido consideradas ruido. Sin embargo, sonidos asociados a oficios que están entre lo industrial y lo artesanal, van añadiéndose a rasgos de cultura que los acoge y redefine, incorporándolos a la vida cotidiana. Aquellos "ruidos" no se constituyen por sí mismos en un paisaje lo-fi sino que, dependiendo de la relación que establezcan con su entorno, pueden hacer parte de un paisaje equilibrado que inserta en su ambiente sonidos que le identifican. En San Nicolás las máquinas aportan la condición acústica al territorio ya que suman al paisaje su extension of this research process in the areas where residents are actively involved.

Today, when architecture is brief in nature and tailored to the needs of global capital, when networks are currently modifying the traditional concept of physical space and when places are at the crossroads between the physical and virtual dimensions, the hi-fi soundscape reveals concrete cultural characteristics, acting as an element that prevents culture from being delocalized. The definition of sound territory proposed here synthetizes the space and society concepts through acoustic cultural demonstrations (Audios 8 and 9.)

\section{Acknowledgments}

I would like to thank José Luis Carles for his correction and clarifying comments on this text. 
ritmo de forma sutil. En ese sentido la noción de territorio sonoro aquí propuesta avala el concepto de "legibilidad" de Lynch pues los objetos sonoros que lo componen contribuyen a un paisaje sonoro discernible. Según nuestra percepción, y según resultó del trabajo con los habitantes, es el sonido del tráfico y no el de las máquinas el que agrede y tensa el paisaje hacia la categoría lo-fi.

Respecto a la experiencia investigativa cabe anotar que las metodologías de carácter interdisciplinar desarrolladas en la investigación ampliaron la comprensión del lugar. La interlocución de los diferentes profesionales, desde la historia, el espacio y lo sensible, dan pie a la construcción de herramientas para una mejor administración de nuestro entorno. Con todo, se detectó la necesidad de seguir trabajando con los residentes del barrio para precisar mejor las relaciones con su hábitat, por lo que se ha continuado el proceso donde tengan más participación.

Hoy en día, cuando la arquitectura se acomoda a los flujos de capital global y es efímera por necesidad, cuando las redes están modificando el concepto tradicional de espacio físico, cuando los lugares son lo que resulta de la intersección del espacio físico y el espacio virtual, el paisaje sonoro hi-fi da cuenta de rasgos culturales concretos y es uno de los elementos que contrarresta la deslocalización de la cultura. La definición de territorio sonoro aquí propuesta, sintetiza espacio y sociedad a través de manifestaciones culturales que tienen una expresión acústica (audios 8 y 9).

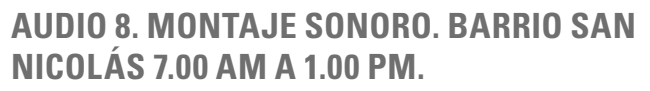

AUDIO 8. AUDIO MONTAGE. SAN NICOLAS, 7:00 AM T0 1:00 PM

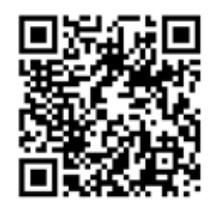

https://www.youtube.com/watch?v=wEg0cf6ZcZo
AUDIO 9. MONTAJE SONORO. BARRIO SAN NICOLÁS 1.00 PM A 7.00 PM.

AUDIO 9. AUDIO MONTAGE. SAN NICOLÁS, 1:00 PM T0 7:00 PM

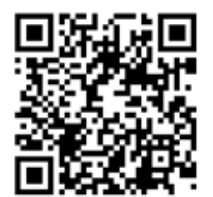

https://www.youtube.com/watch?v=apojCfJPMl8 


\section{Agradecimientos}

Quiero expresar mi agradecimiento a José Luis Carles por sus esclarecedores y certeros comentarios al texto.

\section{Bibliografía}

ALONSO, Miguel. Sonido y sociabilidad: consistencia bioacústica en espacios públicos. En: Espacios sonoros, tecnopolítica y vida cotidiana. Aproximaciones a una antropología sonora. Barcelona, Edición de la Orquestra del Caos 2005. p. 38-51.

ASDRUBALI, Francesco; D'ALESSANDR0, Francesco; BALDINELLI, Giorgio y SCHULTE-FORTKAMP, Brigitte. From the soundscape to the architectural redevelopment of an outdoor public space. En: Forum Acusticum (2014, Krakow, Polonia).

AUGOYARD, Jean-François. Deficiencies in the research about architectural and urban ambient environment and proposition of new tools. The sound example. En: First international workshop about architectural and urban ambient environment (2002, Nantes, Francia). [Consulta: 10 septiembre 2015]. Disponible en: http:// doc.cresson.grenoble.archi.fr/opac/doc_num. php?explnum_id=324.

BANERJEE, Tridib, ed. y SOUTHWORTH, Michael, ed. City sense and city design. Writings and projects of Kevin Lynch. Cambridge, Massachusetts, MIT Press. 2002. ISBN 0-262-62095-2.
BERGER, John. Modos de ver. Barcelona, Gustavo Gili. 2000. ISBN 8425218071.

CARLES, José Luis. El paisaje sonoro, una herramienta interdisciplinar: análisis, creación y pedagogía con el sonido. En: Encuentros iberoamericanos sobre paisajes sonoros (2007, Madrid, España). [Consulta: septiembre 10 de 2015]. Disponible en: http://cvc.cervantes.es/artes/paisajes_sonoros/p_ sonoros01/carles/carles_01.htm.

CARLES, José Luis. Identidad sonora urbana. [En línea] Estudio de música electroacústica. [Fecha de consulta: 19 octubre 2015]. Disponible en: http:// www.eumus.edu.uy/eme/ps/txt/carles.html.

ECHEVERRI, Rafael. Reflexiones sobre lo rural: economía rural, economía de territorios. [En línea]. En: DIRVEN, Martine. Hacia una nueva definición de rural con fines estadísticos en América Latina. Santiago, CEPAL. 2011. [Consulta: octubre de 2015]. Disponible en: http://www.iadb.org/intal/ intalcdi/PE/2011/08534.pdf.

GARCíA, Noel. Alarmas y sirenas: sonotopías de la conmoción cotidiana. En: Espacios sonoros, tecnopolítica y vida cotidiana. Aproximaciones a una antropología sonora. Barcelona, Edición de la Orquestra del Caos. 2005. p. 12-25.

GEHL, Jan. Cities for people. Washington DC, Island Press. 2010. ISBN 13 978-1-59726-573-7.

KANG, Jian. Urban sound environment. London, Taylor and Francis. 2007. ISBN 0-415-35857-4. 
KEIZER, Garret. The unwanted sound of everything we want. A book about noise. New York, Public Affairs. 2010. ISBN 978-1-586-48862-8.

KRAUSE, Bernard. The niche hypothesis: A hidden symphony of animal sounds, the origins of musical expression and the health of habitats. The Soundscape Newsletter (06): 6-10, junio 1993.

LYNCH, Kevin. La imagen de la ciudad. Barcelona, Gustavo Gili. 1998. ISBN 8425217482.

Administración del paisaje. Bogotá, Norma. 1992. ISBN 958-04-2027-0.

SANTOS, Milton. La naturaleza del espacio; técnica y tiempo, razón y emoción. Barcelona, Ariel. 2000. ISBN 84-344-3460-1.

Metamorfosis del espacio habitado. Barcelona, Oikos-Tau. 1996. ISBN 84-281-0890-0.

SCHAEFFER, Pierre. Tratado de los objetos musicales. Madrid, Alianza. 2003. ISBN 84-206-8540-2.

SCHAFER, Murray Raymond. The soundscape: our sonic environment and the tuning of the world. Rochester, Vermont, Destiny Books, 1994. ISBN 0-89281-455-1.

SOUTHWORTH, Michael. The Sonic Environment of Cities. Environment and Behavior 1(1): 49-70, junio 1969. DOI 10.1177/001391656900100104.

TO0P, David. Resonancia siniestra. El oyente como médium. Buenos Aires, Caja Negra. 2013. ISBN 978-987-1622-21-4.
TRUAX, Barry, ed. Acoustic space. En: Handbook for acoustic ecology. Cambridge Street Publishing. 1999. [Fecha de consulta: 10 septiembre 2015]. Disponible en: http://www.sfu.ca/sonic-studio/ handbook/Acoustic_Space.html.

VASQUEZ, Edgar. Historia de Cali en el siglo XX. Sociedad, economía, cultura y espacio. Cali, Artes gráficas del Valle. 2001. ISBN 958-33-2904-5. 